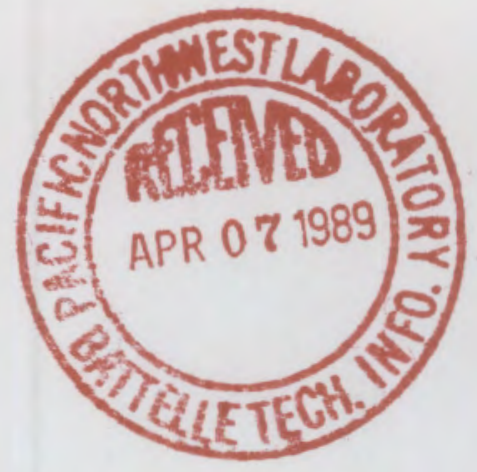

\title{
Feasibility Testing of In Situ Vitrification of Arnold Engineering Development Center Contaminated Soils
}

\author{
C. L. Timmerman \\ March 1989 \\ Report Prepared by \\ Pacific Northwest Laboratory \\ Battelle Boulevard \\ P. O. Box 999 \\ Richland, Washington 99352 \\ under Project No. 14384 \\ for \\ Oak Ridge National Laboratory \\ Oak Ridge, Tennessee 37831 \\ operated by \\ MARTIN MARIETTA ENERGY SYSTEMS, INC. \\ for the \\ U.S. Department of Energy \\ under subcontract DE-AC05-84OR21400
}




\title{
DISCLAIMER
}

This report was prepared as an account of work sponsored by an agency of the United States Government. Neither the United States Government nor any agency thereof, nor Battelle Memorial Institute, nor any or their employees, makes any warranty, expressed or implied, or assumes any legal liability or responsibility for the accuracy, completeness, or usefulness of any information, apparatus, product, or process disclosed, or represents that its use would not infringe privately owned rights. Reference herein to any specific commercial product, process, or service by trade name, trademark, manufacturer, or otherwise does not necessarily constitute or imply its endorsement, recommendation, or favoring by the United States Government or any agency thereof, or Battelle Memorial Institute. The views and opinions of authors expressed herein do not necessarily state or reflect those of the United States Government or any agency thereof.

\author{
PACIFIC NORTHWEST LABORATORY \\ operated by \\ BATTELLE MEMORIAL INSTITUTE \\ for the \\ UNITED STATES DEPARTMENT OF ENERGY \\ under Contract DE-ACO6-76RLO 1830
}

Printed in the United States of America
Available from
National Technical Information Service
United States Department of Commerce
5285 Port Royal Road
Springfield, Virginia 22161
NTIS Price Codes
Microfiche A01
Printed Copy
Pages
$001-025$
$026-050$
$051-075$




\title{
Feasibility Testing of In Situ Vitrification of Arnold Engineering Development Center Contaminated Soils
}

\author{
C. L. Timmerman \\ March 1989 \\ Report Prepared by \\ Pacific Northwest Laboratory \\ Battelle Boulevard \\ P.0. Box 999 \\ Richland, Washington 99352 \\ under Project No. 14384 \\ for \\ Oak Ridge National Laboratory \\ Oak Ridge, Tennessee 37831 \\ operated by \\ MARTIN MARIETTA ENERGY SYSTEMS, INC. \\ for the \\ U.S. Department of Energy \\ under subcontract DE-ACO5-840R21400
}





\section{SUMMARY}

Process feasibility studies using in situ vitrification (ISV) were successfully performed on two different site soils from the Arnold Engineering Development Center (AEDC) located in the southern portion of middle Tennessee. This effort was directed through the U.S. Department of Energy Hazardous Waste Remedial Action Program (HAZWRAP) Office managed by Martin Marietta Energy Systems. In situ vitrification is a thermal treatment process that converts contaminated soils and wastes into a durable glass and crystalline form. During processing, heavy metals or other inorganic constituents are retained and immobilized in the glass structure; organic constituents are typically destroyed or removed for capture by the off-gas treatment system.

The bench-scale ISV testing results, reported herein, indicate that the two AEDC sites may be successfully processed by ISV. Site 1 is a general landfill area for which ISV processed clean soil to prove that ISV could meit the soil type from that area. The other area, Site 10, is a fire training pit that is contaminated with fuel oils and heavy metals from fire training exercises. Actual site material was processed by ISV to determine its feasible application to those contaminated soils. Initial testing and analyses of the soils determined that a lower melting, electrically conductive, fluxing additive (such as sodium carbonate) is required as an addition to the soil for ISV processing to work effectively. With the additive, ISV processing was successful on both soil types. With the high destruction of organics and high retention of inorganics in the melt, the small percentage of particulate and gaseous releases can be effectively retained by a conventional wet scrubbing and filtering system appropriately designed to meet necessary criteria established for airborne releases.

Analytical efforts for this project were directed towards evaluating the organic destruction and migration effects of ISV processing on the Site 10 contaminated soil. No significant migration of hydrocarbon contaminants was detected in the surrounding soil. Off-gas releases of the hydrocarbons indicated a greater than $98 \%$ destruction efficiency by the ISV process. Leach testing using Extraction Procedure (EP) Toxicity and Toxic 
Characteristics Leach Procedure (TCLP) showed that all metals of concern were below maximum permissible limits, indicating that the ISV process produces a nonhazardous product. All these favorable results indicate that ISV could be used to treat contaminated soils (specifically site 10 ) at the AEDC site. Based on this information, it is recommended to proceed with a pilot-scale test at the AEDC Site 10 fire training pit to verify this performance. 


\section{ACKNOWLEDGMENTS}

The author gratefully acknowledges Martin Marietta Energy Systems, Inc. and Arnold Engineering Development Center for providing Pacific Northwest Laboratory the opportunity to perform this testing. The author would also like to thank Jim Jeffs for his efforts associated with test preparation, operations, and analyses in support of this program. High-quality analytical staff greatly assisted the interpretation of the data provided in this report--these people included: Mary Ann Reimus, Frank Hara, Rich Hallen, and George Meadows. 



\section{CONTENTS}

SUMMARY ........................... . ... i ...

ACKNOWLEDGMENTS ....................... . . .

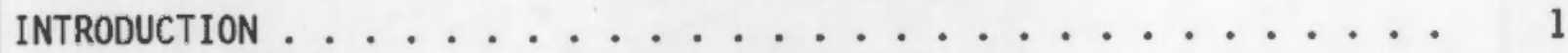

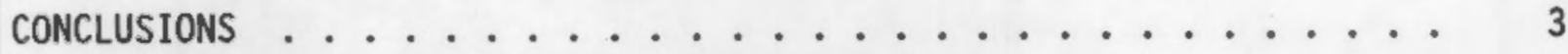

PROCESS DESCRIPTION AND STATUS OF DEVELOPMENT $\ldots \ldots$

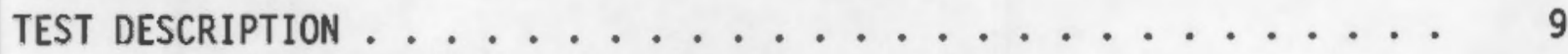

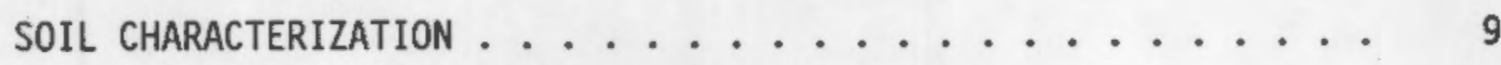

Viscosity and Electrical Conductivity . . . . . . . 11

Melt Behavior of $\mathrm{Na}_{2} \mathrm{CO}_{3}-\mathrm{Soil}$ Mix Layering . . . . . . . 11

TEST EQUIPMENT AND SETUP ....................... 14

TEST OPERATIONS ............................... 17

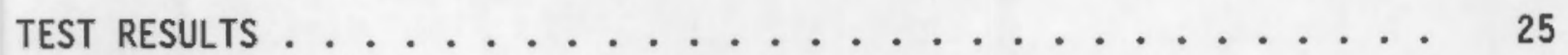

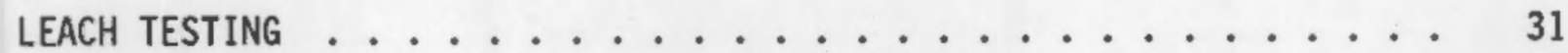

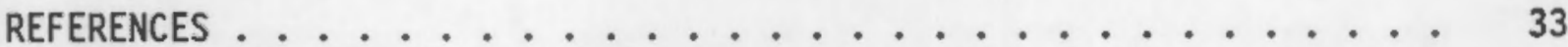

APPENDIX A: AEDC SITE 1 AND SITE 10 SOIL ANALYSIS . . . . . . . A.1

APPENDIX B: CH2M HILL AEDC SITE 10 DATA ............. B. 1 



\section{FIGURES}

1 Process of In Situ Vitrification ............... 5

2 ISV Bench-Scale System ................ 10

3 AEDC Soil ISV Operating Viscosity for Site $10 \ldots 12$

4 AEDC Soil ISV Operating Electrical Conductivity for

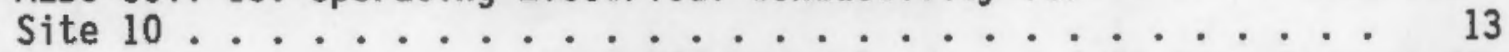

5 Engineering-Scale ISV Processing Container ......... 15

6 Modified Bench-Scale Containers Placed Inside the

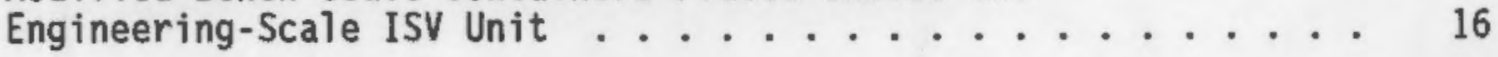

7 Site 1 Soil Configuration .................. 18

8 Site 10 Soil Configuration ................. 18

9a Off-Gas Sample Train A for Particulates ........... 19

9b Off-Gas Sample Train B for Organics ............ 19

10 AEDC Site 1 Vitrified Block ............... 21

11 AEDC Site 10 Vitrified Block .............. 22

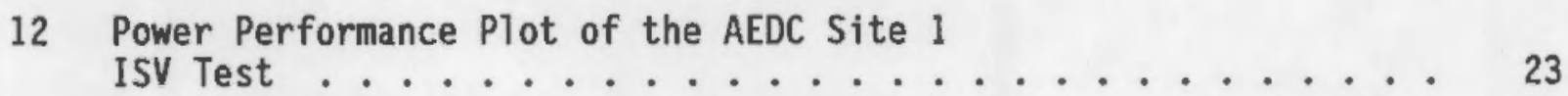

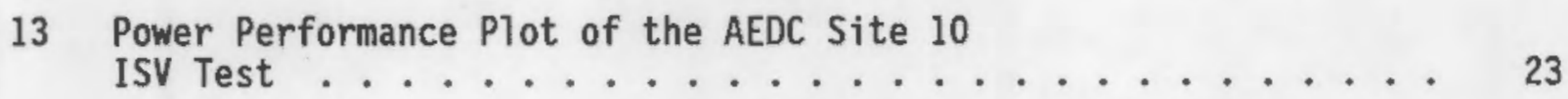

14 Interior View of AEDC Site 1 Vitrified Block ....... 26

15 Interior View of AEDC Site 10 Vitrified Block . . . . . 27 


\section{TABLES}

1 Testing Units for Developing In Situ Vitrification

Technology ....................

2 Particulate Releases from the AEDC Site 1 and Site 10 ISV Tests .................. 28

3 AEDC Site 1 and Site 10 Organic Off-Gas Analyses ........ 30

4 EP Toxicity and TCLP Results for the ISV Product . . . . . . . 32 


\section{INTRODUCTION}

As management of hazardous materials gains increased attention in the United States and throughout the world, new, more effective technologies are being sought to immobilize and/or destroy the materials either in situ for wastes previously disposed of or at the waste generation site. New and proposed environmental regulations are making landfill disposal very costly and are moving toward severely limiting future land disposal. Furthermore, the extended liability associated with future environmental impairment provides a significant incentive to dispose of and delist hazardous chemical wastes within the secured site or waste site boundary.

Pacific Northwest Laboratory $(\mathrm{PNL})^{(\mathrm{a})}$ is developing a remedial action process for contaminated soils that is significant in its application to these concerns. The process, called in situ vitrification (ISV), was initially developed to demonstrate a potential technology for disposal of soil contaminated with transuranic waste at the Hanford Site in southeastern Washington, although recent tests have shown that many hazardous chemical wastes are also destroyed or immobilized as a result of the treatment. In situ vitrification was originally developed for the Department of Energy by PNL. This report presents evidence that ISV also has applicability to Arnold Engineering Development Center (AEDC) contaminated soils, which are contaminated with fuel oils and heavy metals from fire training exercises.

In situ vitrification is a thermal treatment process that converts contaminated soils into a chemically inert and stable glass and crystalline product. The ISV process could potentially be applied to many contaminated soil sites at AEDC. The processing would be performed in place; high temperature would destroy or remove organic contaminants, and the glass would immobilize any inorganic contaminants. All these functions would be performed in one processing step.

This report presents the results of two bench-scale ISV tests conducted for Martin Marietta Energy Systems. The primary objective of this study was

(a) The Pacific Northwest Laboratory is operated for the U.S. Department of Energy by Battelle Memorial Institute under Contract DE-AC06-76RLO 1830. 
to determine the applicability of the ISV process to soils contaminated with fuel oils. To accomplish this objective, initial bench-scale tests--one on Site 1 soils of a landfill and one on Site 10 soils from a fire training pit--were performed. Testing results determined the destruction of organics and the retention of inorganics in the vitrified product. Fractional release of contaminants to the off-gas treatment system and leaching characteristics of the two vitrified materials were also determined.

Given the results of this report on organic-contaminated soils and ISV applications to specific sites, ISV can offer a long-term improvement to remediation of AEDC contaminated soil sites. 


\section{CONCLUSIONS}

Feasibility testing of the ISV process was successfully performed on two different site soils and contaminants from the AEDC site. Analyses of the data from the two tests provide conclusions regarding the performance of the ISV process to AEDC soils:

- Processing parameters from both tests demonstrated the feasibility of using ISV to process both of these contaminated soil types into a more compact and environmentally stable (immobilized) form with the use of a fluxing addivite such as sodium carbonate.

- Organic contaminants were effectively destroyed to $>98 \%$ level for the fuel oil-contaminated Site 10 soil. The small particulate and gaseous releases can be effectively retained by the appropriate design of a conventional off-gas treatment system, consisting of a wet scrubber and filtering media.

- Leach testing results per the Extraction Procedure (EP) Toxicity and Toxic Characteristics Leach Procedure (TCLP) showed that all metals of concern were below the maximum permissible limit. This indicates that inorganic contaminants are immobilized to a level that should allow the site to be listed as nonhazardous material according to regulatory criteria.

- $5 \%$ to $10 \%$ sodium carbonate additions are necessary to process AEDC site soils. These fluxing additives can be easily added by soil mixing or injection techniques.

Bench-scale testing indicates the potential for ISV treatment of organic contaminated soils from the fire training pit of the AEDC Site 10. Based on the results of the feasibility tests, it is recommended to perform a pilotscale test at the AEDC Site 10 fire training pit to verify the efforts presented in this report prior to actual remediation of the site with ISV. 



\section{PROCESS DESCRIPTION AND STATUS OF DEVELOPMENT}

In situ vitrification has been developed as a remedial action process for soils contaminated with hazardous chemical wastes and/or radionuclides. Figure 1 illustrates the operation of the ISV process. A square array of four molybdenum (Mo)/graphite electrodes is inserted into the ground to the desired treatment depth. Because soil is not electrically conductive when its moisture has been driven off, a conductive mixture of flaked graphite and glass frit is placed among the electrodes to serve as a starter path. An electrical potential is applied to the electrodes to establish an electrical current in the starter path. The flow of current heats the starter path and surrounding soil to well above the initial soil-melting temperatures of $1100^{\circ} \mathrm{C}$ to $1400^{\circ} \mathrm{C}$. The graphite starter path is eventually consumed by oxidation and the current is transferred to the molten soil, which is processed at temperatures between $1450^{\circ} \mathrm{C}$ and $2000^{\circ} \mathrm{C}$. As the molten or vitrified zone grows, it incorporates or encapsulates any radionuclides and nonvolatile hazardous elements, such as heavy metals, into the glass structure. The high temperature of the process destroys organic components by pyrolysis. The pyrolyzed byproducts migrate to the surface of the vitrified zone, where they

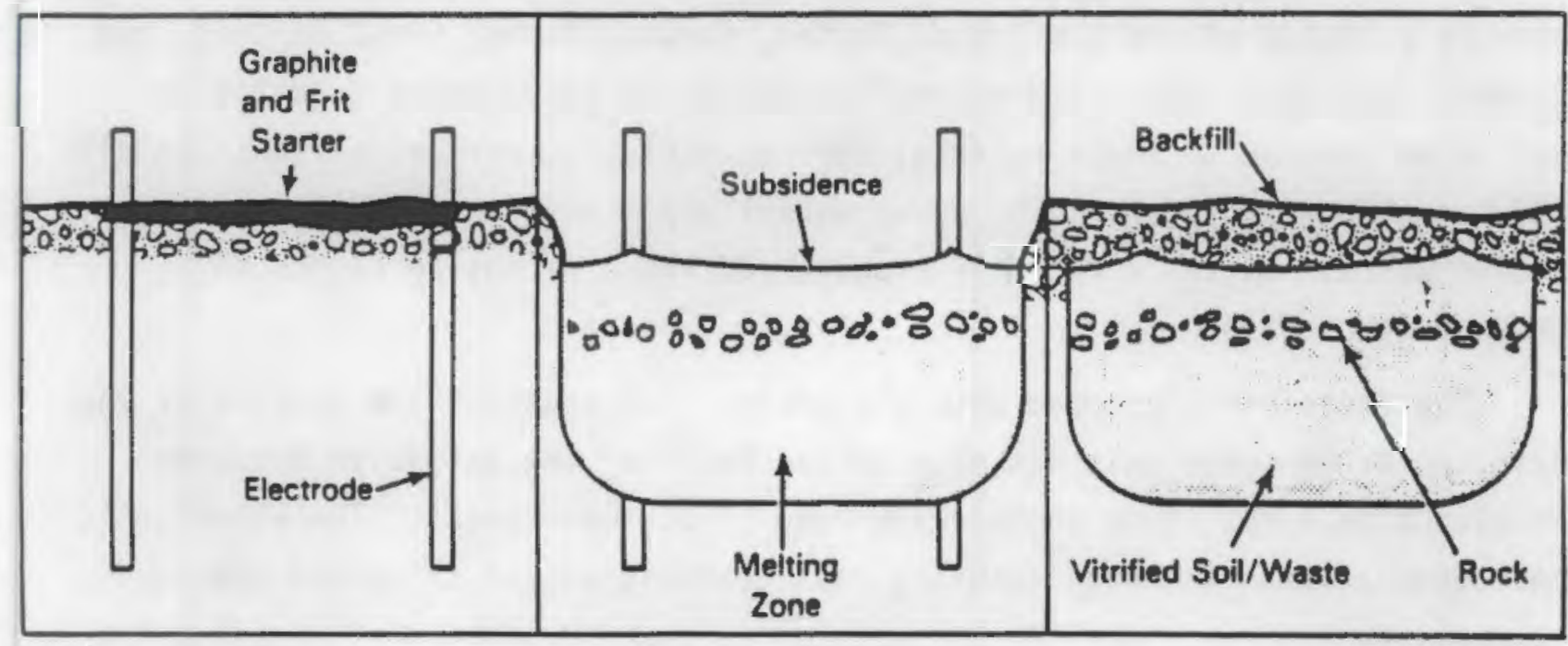

38809094.1

FIGURE 1. Process of In Situ Vitrification 
combust in the presence of air. A hood placed over the area being vitrified directs the gaseous effluents to an off-gas treatment system.

The process can also accommodate a staging operation alternative. In this processing alternative, outlying materials are placed on the surface of an area to be vitrified to increase the effective vitrification depth. Since ISV is a batch operation, this alternative will increase the amount of material vitrified in each batch setting, thereby improving the efficiency of the operation.

Pacific Northwest Laboratory began developing ISV technology in 1980. Since that time, numerous experimental tests under a variety of site conditions and with a variety of waste types have been conducted (Buelt et al. 1987; Timmerman and Oma 1984; Timmerman et a1. 1983; Bue1t and Carter 1986; Carter et a1. 1987). Table 1 describes the different scales of testing units that PNL uses in developing and adapting ISV technology. The successfu1 results of 59 bench-, engineering-, pilot-, and large-scale tests have proven the general feasibility and widespread applications of the process. Also, economic studies have indicated that tremendous economies of scale are attainable with the ISV process (Oma et al. 1983). ISV technology has been refined to the point that it is now ready for technology transfer and commercialization for specific hazardous waste types. The ISV process has been broadly patented within the United States, Canada, Japan, Great Britain, and France. Battelle, Pacific Northwest Laboratories (BNW) holds a partially exclusive license to those patents; BNW has exclusive worldwide rights to all ISV technology except for U.S. governmental applications of ISV to radioactive waste. Battelle recently transferred these licensing rights to Geosafe Corporation.

The decision to proceed with the design, fabrication, and testing of the existing large-scale unit was made on the basis of the extensive database developed as a result of engineering- and pilot-scale tests. The pilot-scale unit demonstrated the process using radioactively spiked soils and provided 
TABLE 1. Testing Units for Developing In Situ Vitrification Technology

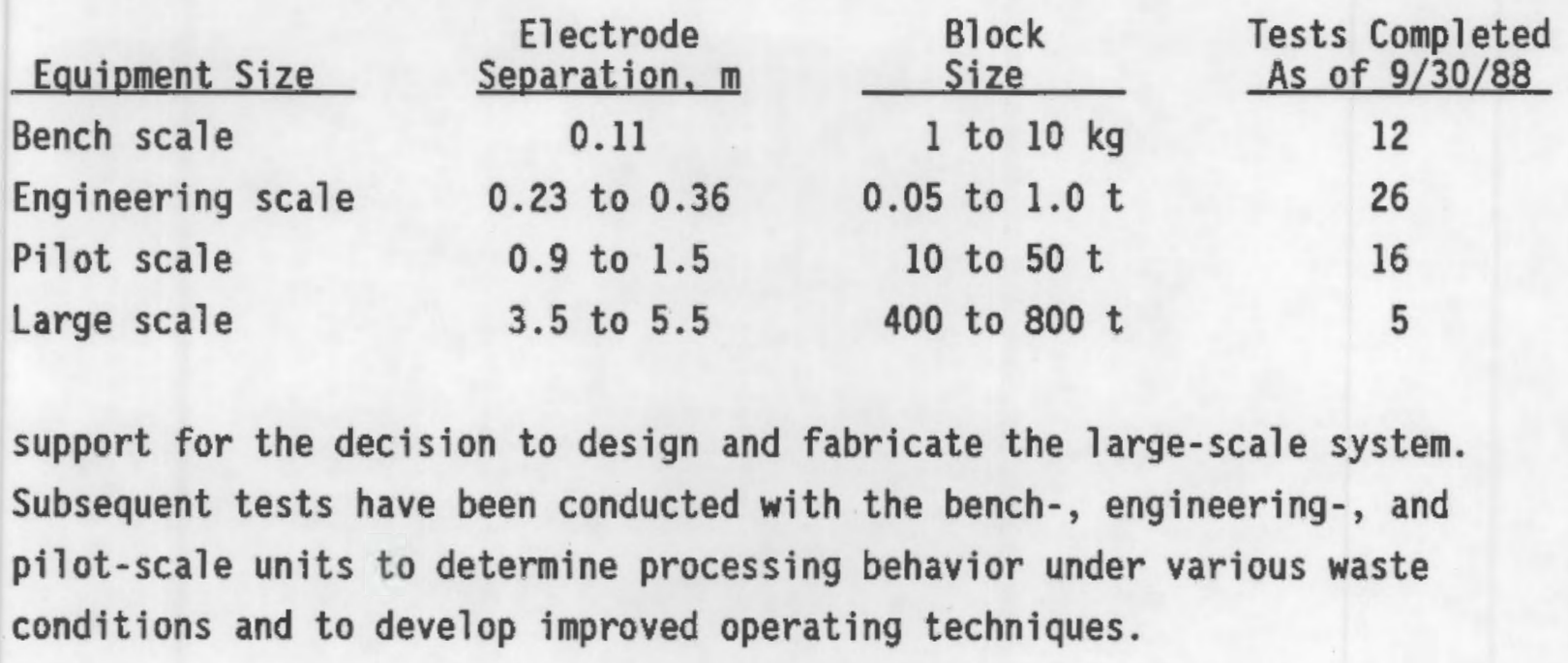





\section{TEST DESCRIPTION}

This section describes the bench- and engineering-scale ISV test equipment and off-gas sampling system, plus the specific test setup and operations used for both the Site 1 and Site 10 AEDC soils. The initial tests performed at the AEDC laboratories were unsuccessful due to the need, later identified, for conductive fluxing soil additives (e.g., sodium carbonate). These onsite tests used the bench-scale system, for which the entire test apparatus, except the electrical power supply and controller, was contained inside a fume hood for each test as shown in Figure 2. Additional testing using fluxing additives was continued at PNL using the engineering-scale system. The engineering-scale system was used instead of the bench-scale system because that power supply better simulates the power density, melt rate, and control of the larger scale operational ISV systems. The specific test equipment used is described in the next section.

\section{SOIL CHARACTERIZATION}

This section covers the laboratory testing results with soils from the AEDC Sites 1 and 10 to determine the extent of fluxing additives and their effect on melt behavior. The testing included: melt and fusion temperatures of $10 \mathrm{wt} \% \mathrm{Na}_{2} \mathrm{O}$ melts of sample AS-10-1 and 2, and AS-1-1 and 8 ; a $5 \mathrm{wt} \% \mathrm{Na}_{2} \mathrm{O}$ melt of AS-10-2; viscosity and electrical conductivity measurements of a $10 \mathrm{wt} \% \mathrm{Na}_{2} \mathrm{O}$ melt of a mixture of Site $10 \mathrm{soil}$; and a study investigating the melt behavior of a melt with a $\mathrm{Na}_{2} \mathrm{CO}_{3}$-soil mixture layered on top of a mixture of Site 10 soil. The results of this testing are given below.

\begin{tabular}{|c|c|c|}
\hline Melt Description & Fusion Temperature, ${ }^{\circ} \mathrm{C}$ & Melt Temperature, ${ }^{\circ} \mathrm{C}$ \\
\hline AS- $10-2^{(a)} / 5 w t \% \mathrm{Na}_{2} \mathrm{O}$ & 1200 & 1450 \\
\hline AS $-10-1 / 10$ wt $\% \mathrm{Na}_{2} \mathrm{O}$ & 1000 & 1100 \\
\hline AS- $10-2 / 10 w t \% \mathrm{Na}_{2} \mathrm{O}$ & 900 & 1000 \\
\hline AS- $1-1 / 10 \mathrm{wt} \% \mathrm{Na}_{2} \mathrm{O}$ & 1100 & 1300 \\
\hline AS- $1-8 / 10 \mathrm{wt} \% \mathrm{Na}_{2} 0$ & 1000 & 1300 \\
\hline
\end{tabular}

(a) See Appendix A for sample identification from Sites 1 and 10. 


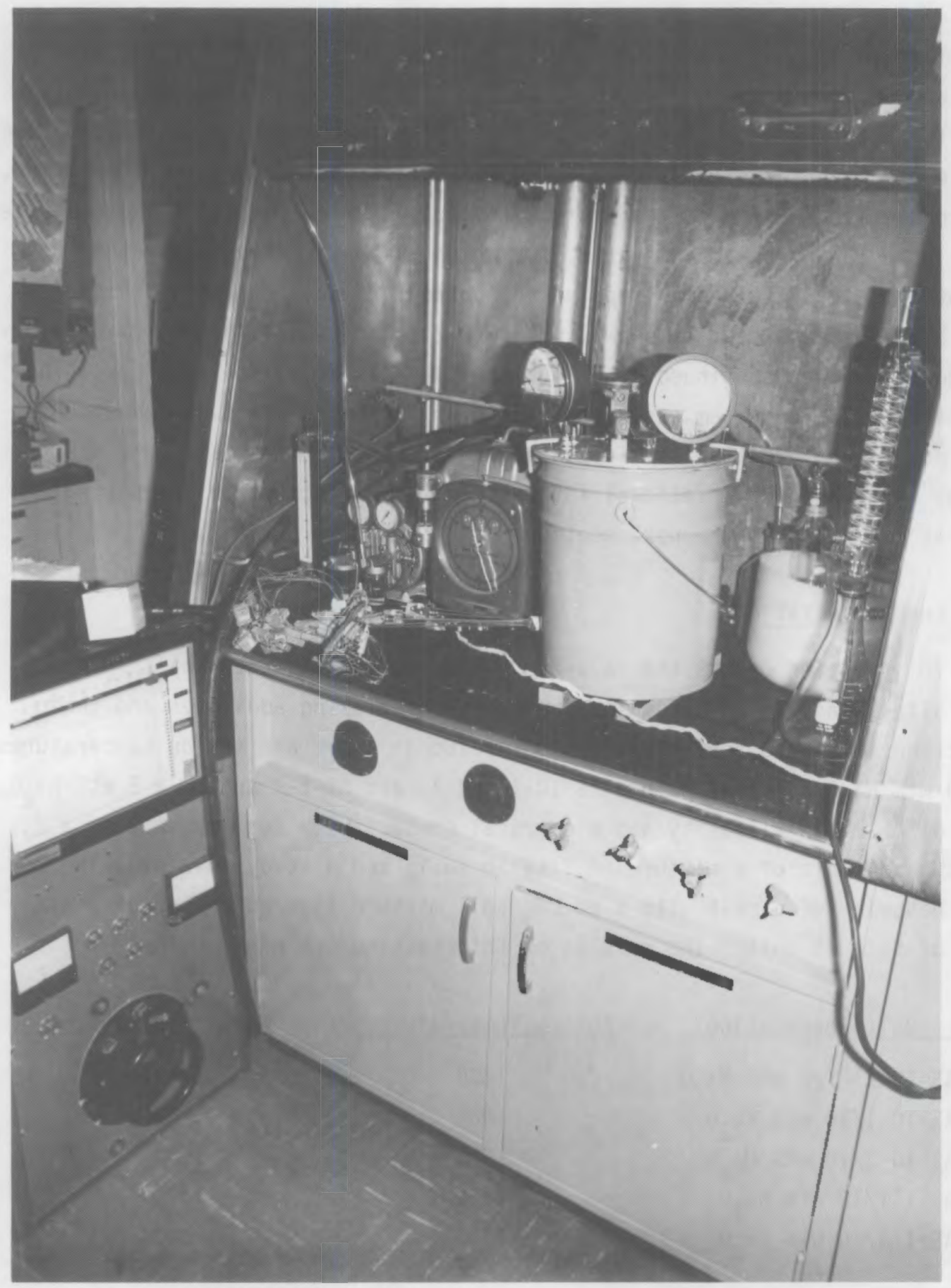

FIGURE 2. ISV Bench-Scale System 


\section{Viscosity and Electrical Conductivity}

A batch consisting of Site 10 soil and a $\mathrm{Na}_{2} \mathrm{CO}_{3}$-soil mix was prepared for viscosity and electrical conductivity measurement of vitrified Site 10 soil. This batch consisted of the identical Site 10 soil mix and $\mathrm{Na}_{2} \mathrm{CO}_{3}$-soil mix used in the layered batch melt behavior study discussed later. The T100P of the glass, temperature of the glass when its viscosity is 100 poise, was determined to be $1436^{\circ} \mathrm{C}$. The electrical conductivity of the glass was determined to range from 0.159 to 0.071 over the temperature span of $1492^{\circ} \mathrm{C}$ to $1269^{\circ} \mathrm{C}$, respectively. Plots depicting the temperature dependence of viscosity and electrical conductivity are provided in Figures 3 and 4 , respectively.

\section{Melt Behavior of $\mathrm{Na}_{2} \mathrm{CO}_{3}$-Soil Mix Lavering}

A layering study gave positive results, indicating that placing a layer of $\mathrm{Na}_{2} \mathrm{CO}_{3}$-soil mixture over Site 10 soil aids melting and produces a homogeneous, vitreous product.

The experimental approach to determining the effect of a top layer of a $\mathrm{Na}_{2} \mathrm{CO}_{3}$-soil mix on the melt behavior of Site 10 soil was as follows. A specific quantity (i.e., $200 \mathrm{~g}$ ) of a mixture of Site 10 soil was placed in a fused-silica crucible. Placed in a layer on top of this soil was $95 \mathrm{~g}$ of a $\mathrm{Na}_{2} \mathrm{CO}_{3}$-soil mixture. This mixture contained $32.5 \mathrm{wt} \% \mathrm{Na}_{2} \mathrm{O}$ on a dry oxide basis. The vitrified material produced from this mixture and the bottom layer of soil has a $\mathrm{Na}_{2} \mathrm{O}$ content of $10 \mathrm{wt} \%$, dry oxide basis. The crucible was then placed in a furnace and held for $1 \mathrm{~h}$ at $1000^{\circ} \mathrm{C}$. The furnace temperature was then increased to $1500^{\circ} \mathrm{C}$ at a linear rate of $200^{\circ} \mathrm{C} / \mathrm{h}$. The crucible was held at $1500^{\circ} \mathrm{C}$ for $2 \mathrm{~h}$, then at $600^{\circ} \mathrm{C}$ for $2 \mathrm{~h}$, and then allowed to slowly cool to room temperature. The heat treatment at $600^{\circ} \mathrm{C}$ anneals the glass and prevents shattering upon cutting. The crucible was then sectioned and the glass examined. Upon examination, the glass was observed to be homogeneous with no traces of devitrification (crystallization), indicating that effective mixing of additive and nonadditive soil had occurred. This method or an injection technique could be employed for applying or mixing the necessary additives with the AEDC soils. 


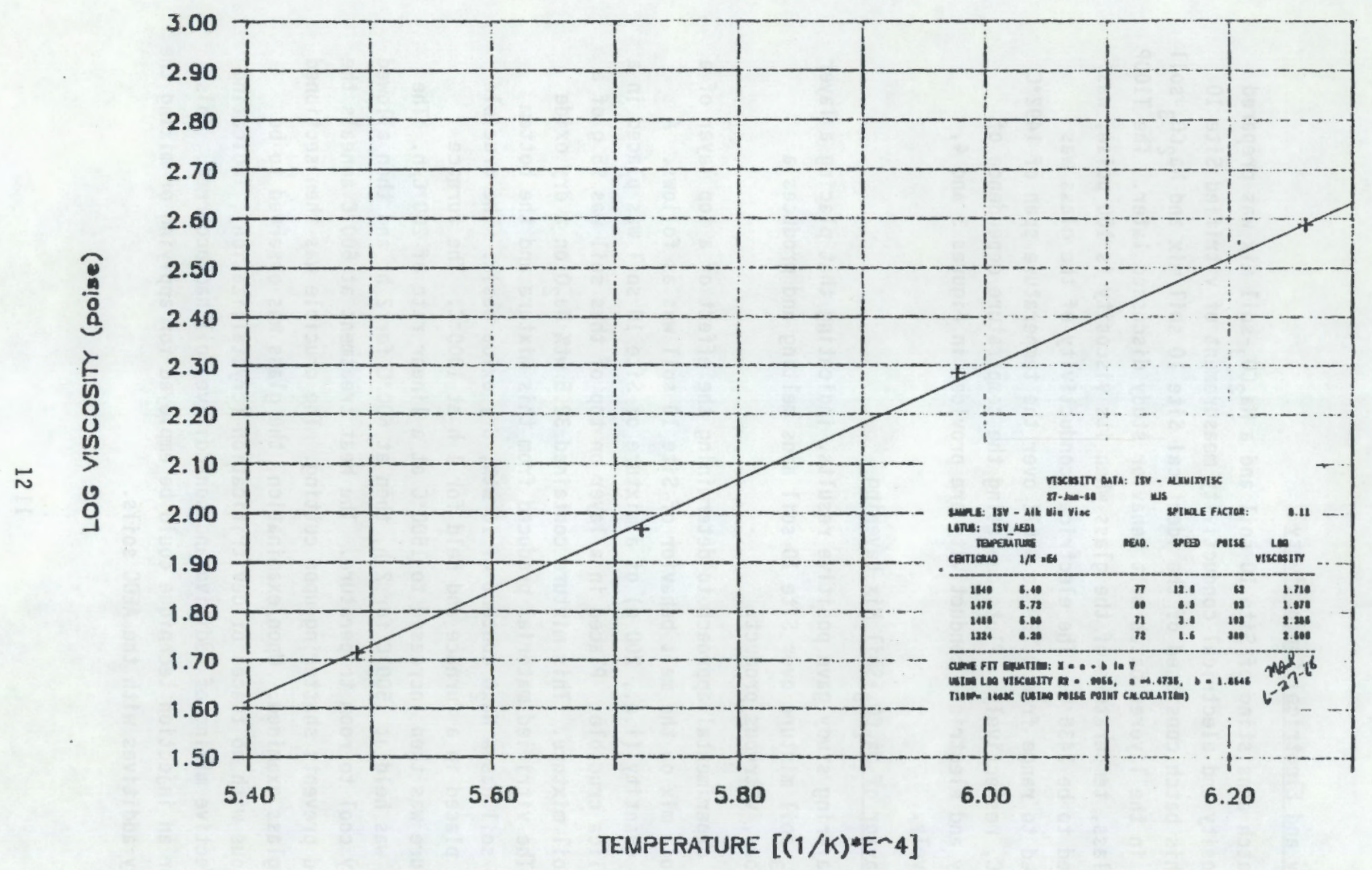

FIGURE 3. AEDC Soil ISV Operating Viscosity for Site 10 


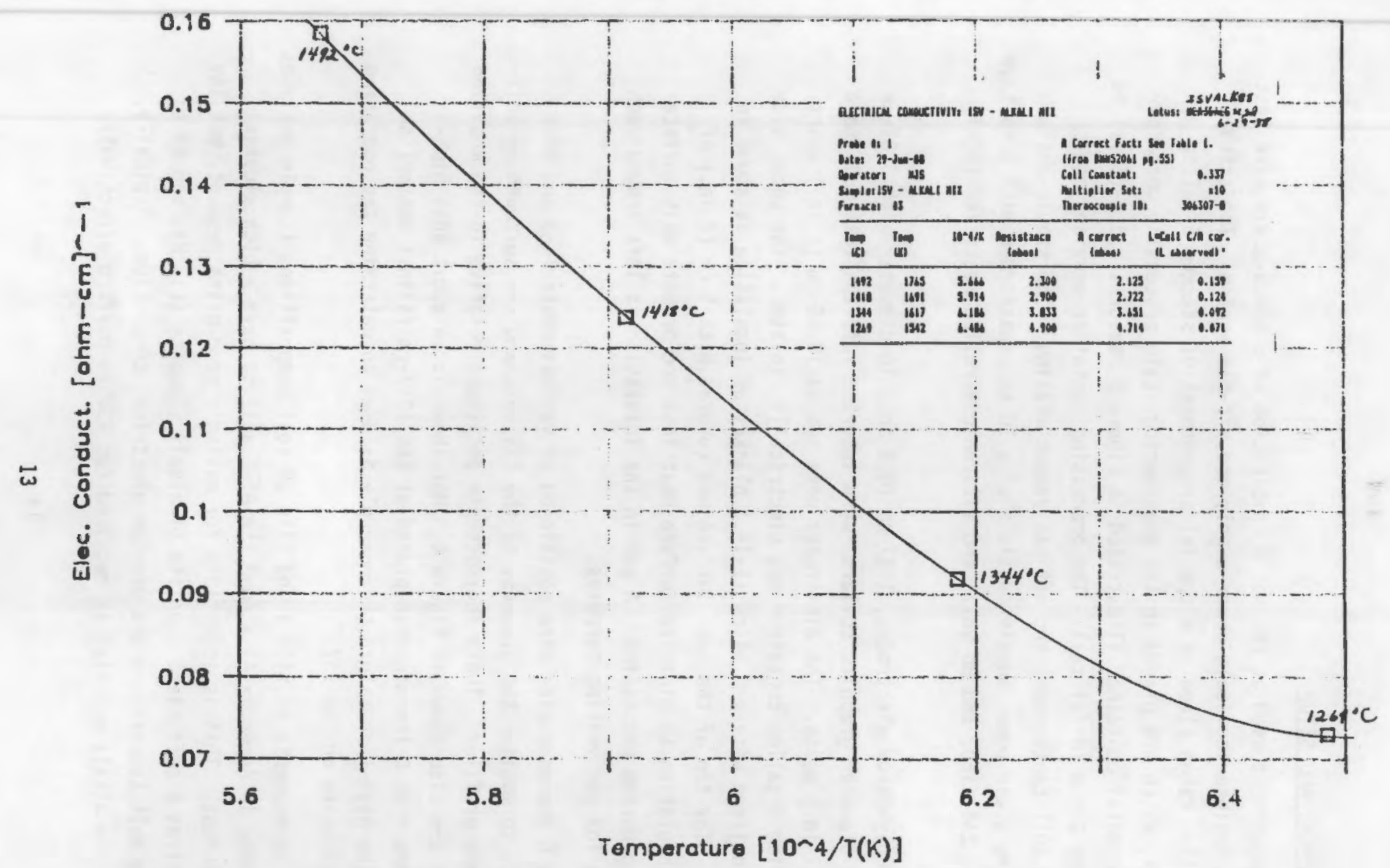

FIGURE 4. AEDC Soil ISV Operating Electrical Conductivity for Site 10 


\section{TEST EQUIPMENT AND SETUP}

The equipment used at PNL was a combination of a bench-scale size test using the engineering-scale power supply and off-gas system. The actual vitrification takes place in a special arrangement of stacked 5-gallon containers, which are placed in the engineering-scale processing container. The sealed metal container illustrated in Figure 5 measures $1.8 \mathrm{~m}(6 \mathrm{ft})$ in diameter by $2.4 \mathrm{~m}(8 \mathrm{ft})$ tall. The processing container provides contaminated soil containment and off-gas vacuum sealing. The single-phase engineering-scale power supply consists of a $10-\mathrm{kW}$ transformer with 4 voltage taps $(400,240,160$, and 80 volt) and silicon-controlled rectifier (SCR) control.

Two molybdenum electrodes, $1.27 \mathrm{~cm}(0.5 \mathrm{in.})$ in diameter with $3.81-\mathrm{cm}$ (1.5-in.)-diameter graphite collars, were inserted into the test soil to a 17.8-cm (7-in.) depth. The electrodes were spaced $10.16 \mathrm{~cm}$ (4 in.) apart. The modified 5-gallon container was electrically isolated. The upper side walls were 1 ined with a $2.54-\mathrm{cm}$ (1-in.) blanket of insulation as shown in Figure 6. The top of the soil surface was covered with $5 \mathrm{~cm}(2 \mathrm{in}$.$) of$ blanket insulation to minimize surface heat loss and promote melt surface subsidence during processing. A gap in the insulation is left around each electrode for gas venting purposes.

Type $K$ thermocouples were positioned at various centerline and side increments to monitor the progress of the ISV melt and the surrounding soil temperature profiles. These thermocouple positions relative to the modified container are also shown in Figure 6 . Not shown is an additional hightemperature type $C$ thermocouple $\mathrm{placed}$ at the $12.7-\mathrm{cm}(5-\mathrm{in}$.$) centerline$ depth. The high-temperature thermocouple is used to determine the operating melt temperature during ISV.

The assessments of Site 1 and Site 10 soil compositions (sample analyses are provided in Appendix A) showed the AEDC soil to have a high alumina/ silica content. This is acceptable for making a good glass product, but ISV also requires a sufficient quantity of alkali elements ( $\mathrm{Li}, \mathrm{Na}$, and $\mathrm{K}$ ) to lower the melt temperature and provide electrical conduction. Typically, 5 wt\% of the alkali material is required for ISV to perform effectively. 


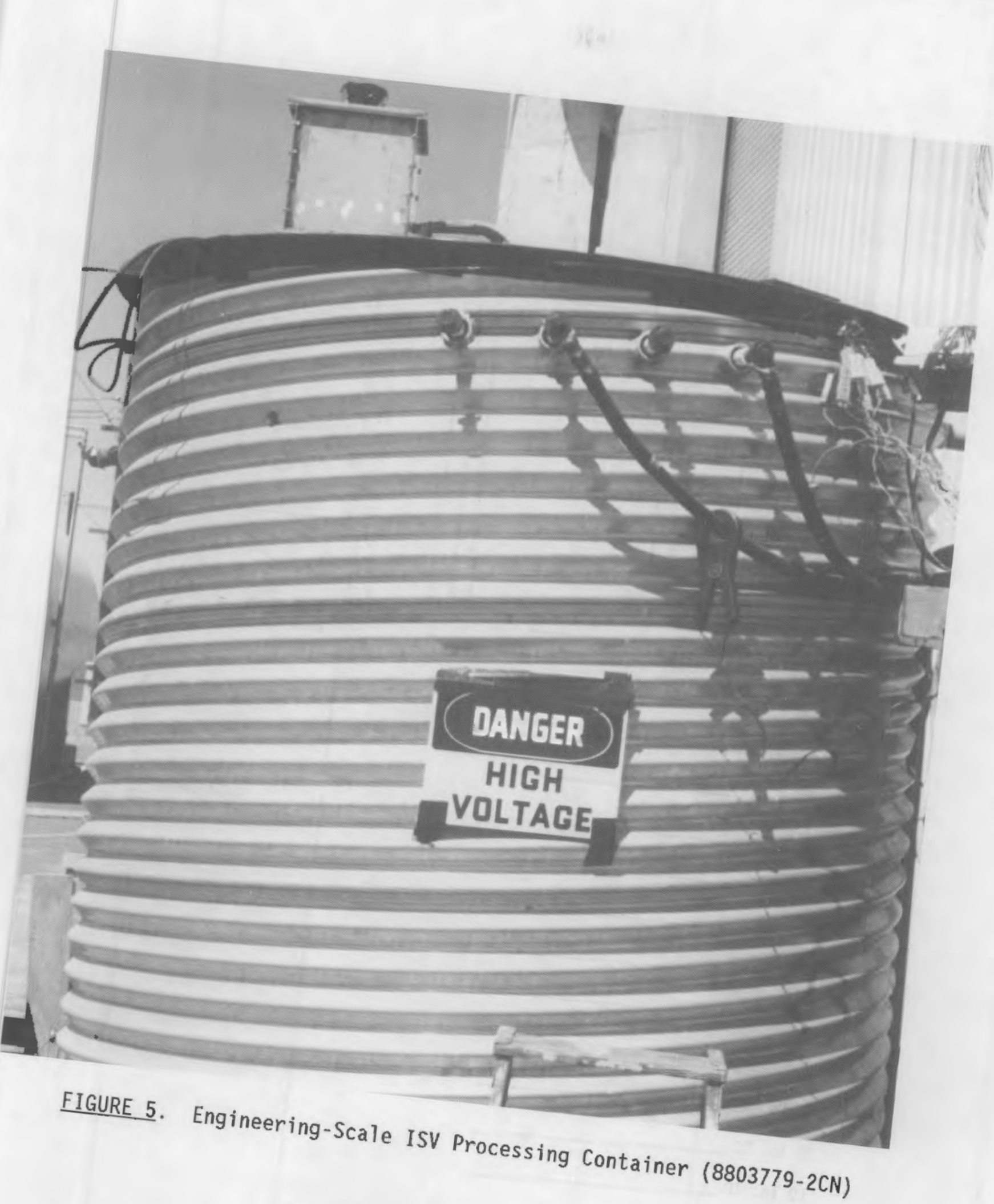




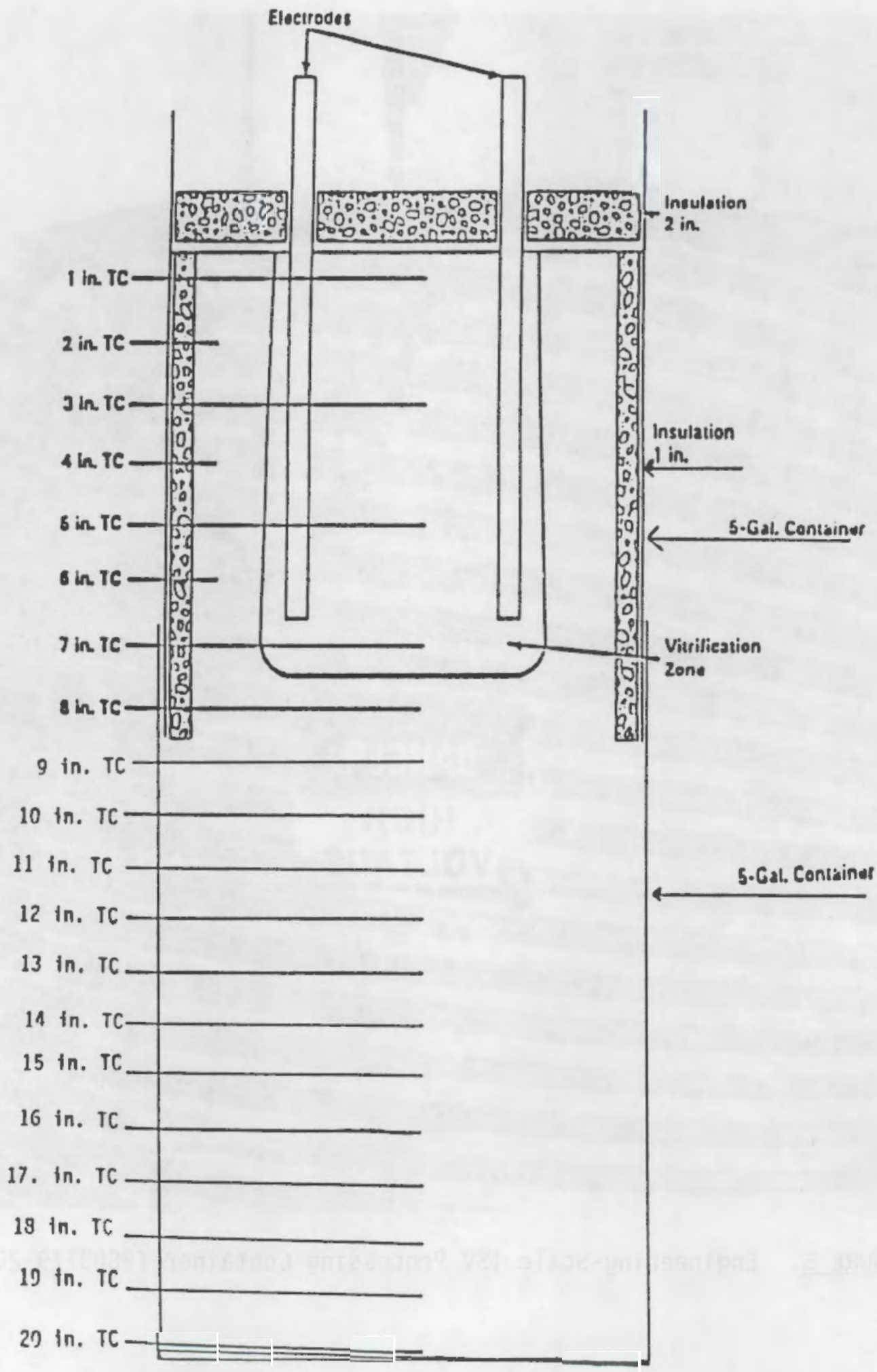

FIGURE 6. Modified Bench-Scale Containers Placed Inside the Engineering-Scale ISV Unit 
Arnold soils contain < 1 wt\% of these materials; therefore, soil fluxing additives were required. Sodium carbonate was added to the $10 \mathrm{wt} \%$ oxidebasis-level to ensure ISV processing.

Figure 7 shows the soil configuration for the Site 1 test: $51 \mathrm{~cm}$ (20 in.) of Site 1 soil, with the top $17.8 \mathrm{~cm}(7 \mathrm{in.})$ mixed with 10 wt\% $\mathrm{Na}_{2} \mathrm{CO}_{3}$. Shown in Figure 8 is the soil configuration for the site 10 test: $7.62 \mathrm{~cm}$ ( 3 in.) of cover soil, $10.16 \mathrm{~cm} \mathrm{(4} \mathrm{in.)} \mathrm{of} \mathrm{sludge} \mathrm{(contaminated}$ soil), and $33 \mathrm{~cm}$ (13 in.) of clean soil. Again, $10 \mathrm{wt} \% \mathrm{Na}_{2} \mathrm{CO}_{3}$ is blended with the soil and contaminants in only the upper $17.8 \mathrm{~cm}(7 \mathrm{in.})$ of the test. The soil from the $17.8-\mathrm{cm}(7-\mathrm{in}$.$) to 51-\mathrm{cm}(20-\mathrm{in}$.$) depth in each test will$ be analyzed to monitor thermal migration effects to the surrounding soil. The contaminated material within the vitrification zone of the upper part of the container will be partially consumed by the ISV melt.

off gas from the vitrification zone was representatively sampled continuously during each test (Figures $9 a$ and $9 b$ ). Train A consisted of a $\mathrm{glass}$ fiber prefilter, four $500-\mathrm{mL}$ gas washing bottles with fritted glass ends, a vacuum pump, a flowmeter, and a flow totalizer. Train B consisted of a condenser, two carbon sample tubes, a 500-g carbon reservoir, a vacuum pump, a flowmeter, and a flow totalizer. Train A determines the particulate releases and Train B provides the organic releases and ISV destruction effectiveness.

\section{TEST OPERATIONS}

Two bench-scale ISV tests were conducted in late June and early July of 1988 to assess the applicability of the ISV process to contaminated soil sites at AEDC. The first test used Site 1 clean surface soil, while the second test used contaminated soil from the Site 10 fire training pit area.

The upper zone of the Site 1 test (see Figure 4) constituted about 12.2 $\mathrm{kg}(27 \mathrm{lb})$ of soil. This $17.8-\mathrm{cm}(7-\mathrm{in}$.$) -depth quantity of soil was blended$ with $2.3 \mathrm{~kg}(5 \mathrm{lb})$ of sodium carbonate to achieve a 10 wt\% concentration on a sodium oxide basis in the vitrified product. Vitrification processing proceeded to the $20.3-\mathrm{cm}$ (8-in.) depth and produced a $6.8-\mathrm{kg}$ (15- $\mathrm{Tb}$ ) glass block over a 3-hour period. This block was cylindrical at the upper region 


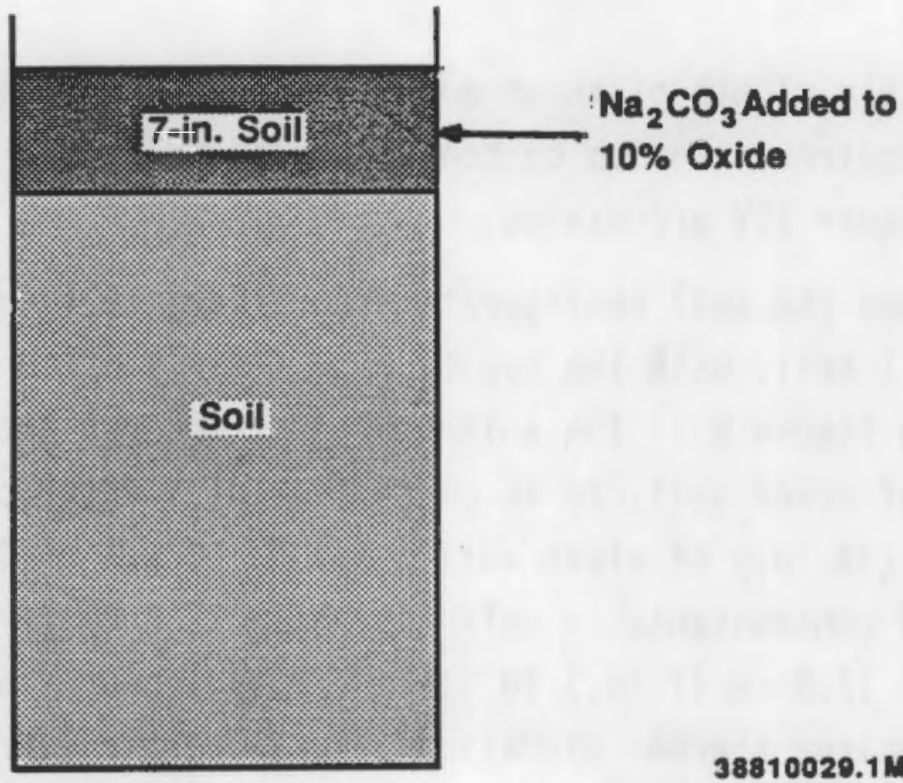

FIGURE 7 . Site 1 Soil Configuration

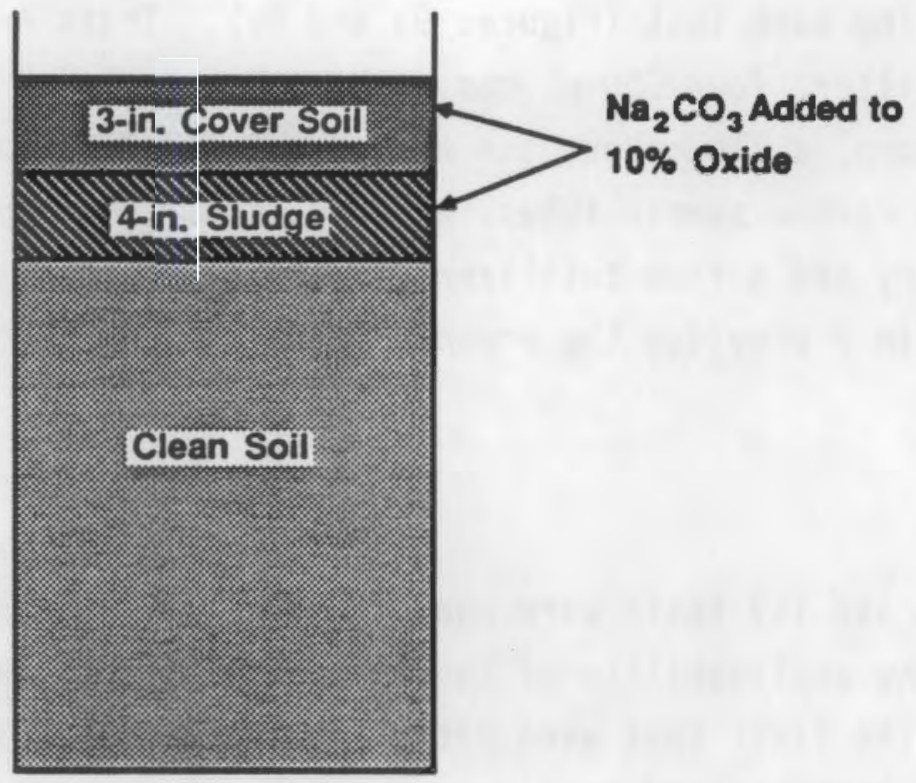

FIGURE 8. Site 10 Soil Configuration 
Top Port of

Engineering-Scale

Offgas Line

Gas-Washing Bottles (4)

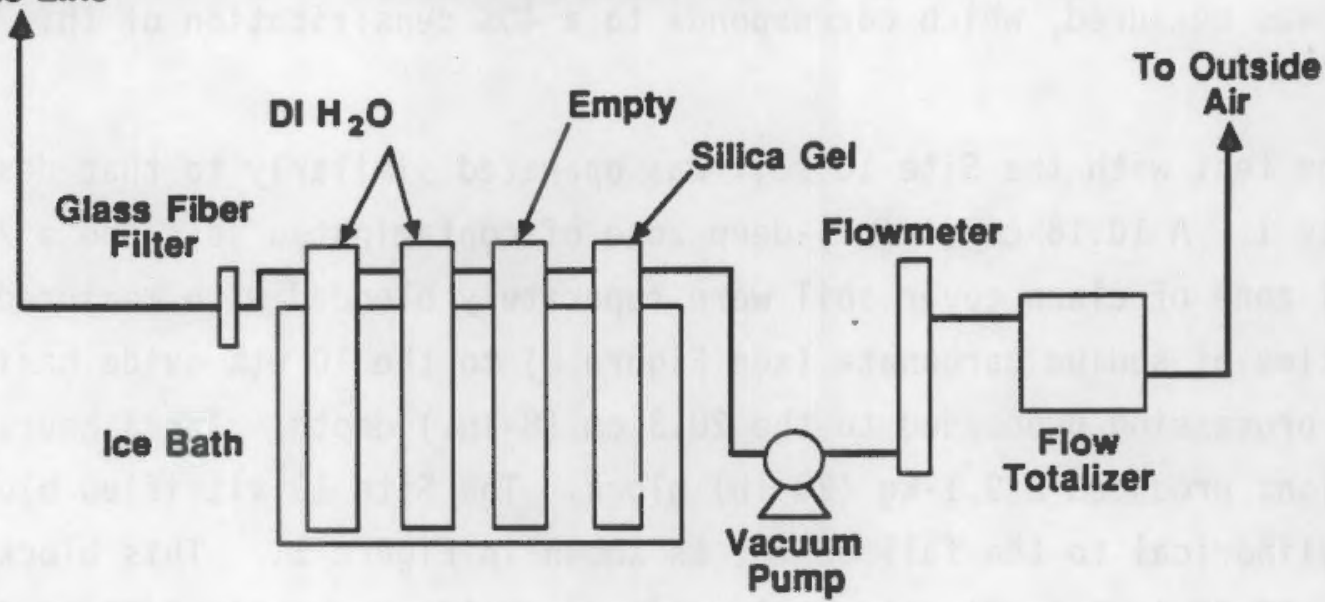

FIGURE 9a. Off-Gas Sample Train A for Particulates

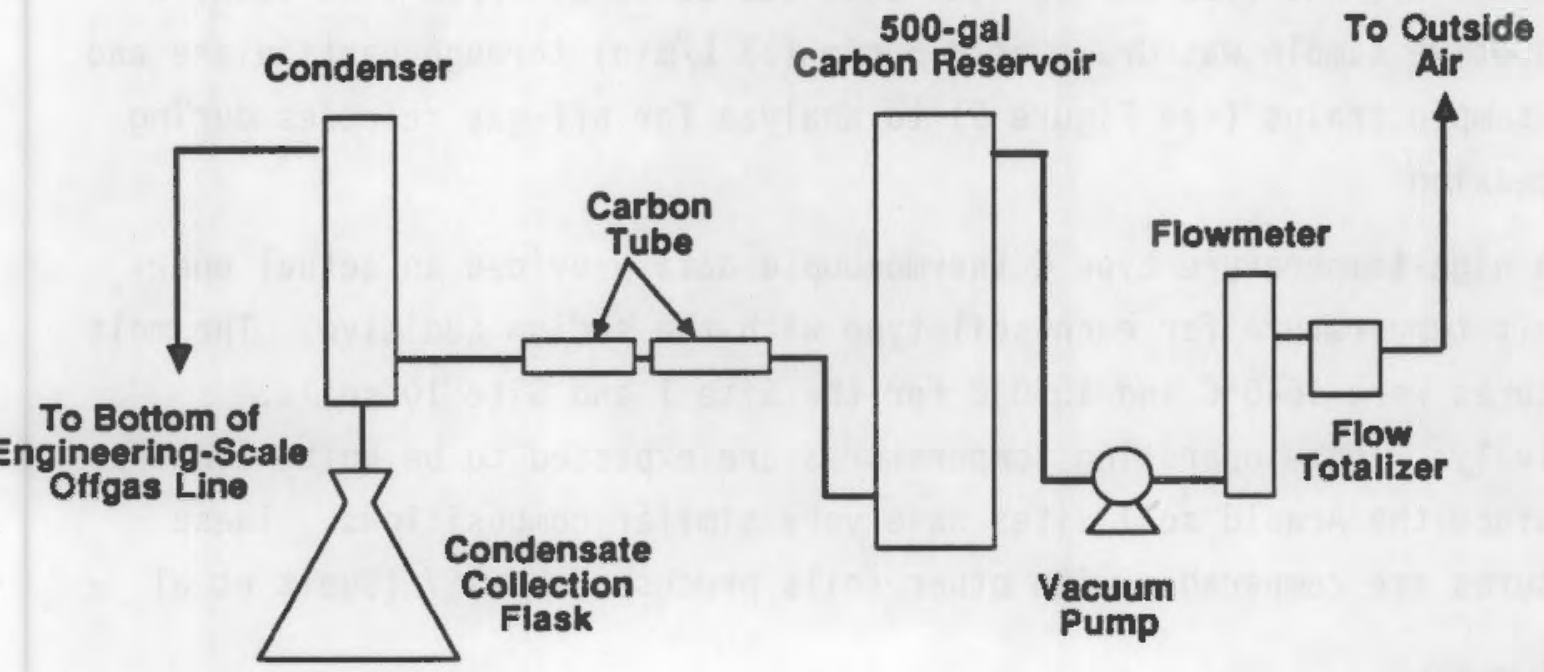

$38810029.2 \mathrm{M}$

FIGURE 9b. Off-Gas Sample Train B for Organics 
and measured $21 \mathrm{~cm}$ (8.25 in.) in diameter. The block tapered toward the bottom as illustrated in Figure 10 . An 8.26-cm (3.25-in.)-deep subsidence region was measured, which corresponds to a $40 \%$ densification of this soit type.

The test with the Site 10 soil was operated similarly to that described for Site 1. A 10.16-cm (4-in.)-deep zone of contaminated soil and a 7.62-cm (3-in.) zone of clean cover soil were separately blended with measured quantities of sodium carbonate (see Figure 8 ) to the 10 wt\% oxide basis. Again, processing proceeded to the $20.3-\mathrm{cm}(8-\mathrm{in.})$ depth. The 3 hours of operations produced a $9.1-\mathrm{kg}(20-1 \mathrm{~b})$ block. The Site 10 vitrified block was more cylindrical to the full depth, as shown in Figure 11. This block was $23.5 \mathrm{~cm}$ (9.25 in.) in diameter. A uniform subsidence region 4.13-cm (1.625in.) deep was measured. The subsidence corresponds to a $20 \%$ densification for this operation.

Average off-gas flow during each test was $30 \mathrm{scfm}$. From this flow, a representative sample was drawn at $0.5 \mathrm{cfm}(13 \mathrm{~L} / \mathrm{min})$ through particulate and organic sample trains (see figure 9) to analyze for off-gas releases during ISV processing.

The high-temperature type $C$ thermocouple data provided an actual operating melt temperature for each soil type with the sodium additive. The melt temperatures were $1640^{\circ} \mathrm{C}$ and $1590^{\circ} \mathrm{C}$ for the Site 1 and Site 10 soils, respectively. These operating temperatures are expected to be quite close as shown, since the Arnold soil sites have very similar compositions. These temperatures are comparable with other soils processed by ISV (Buelt et al. 1987).

Electrical power data for the Site 1 and Site 10 ISV tests are plotted in Figures 12 and 13, respectively. The Site 1 plot shows that a slower, more conservative startup was used during that test. The Site 10 test achieved higher power levels earlier into the test. This can be attributed to the experience gained from operating the Site 1 test first. The total energy consumed for the Site 1 test was $6.1 \mathrm{kWh}$, which provides an energy-tomass ratio of $0.9 \mathrm{kWh} / \mathrm{kg}$. During the Site 10 test, a total of $9.5 \mathrm{kWh}$ of 


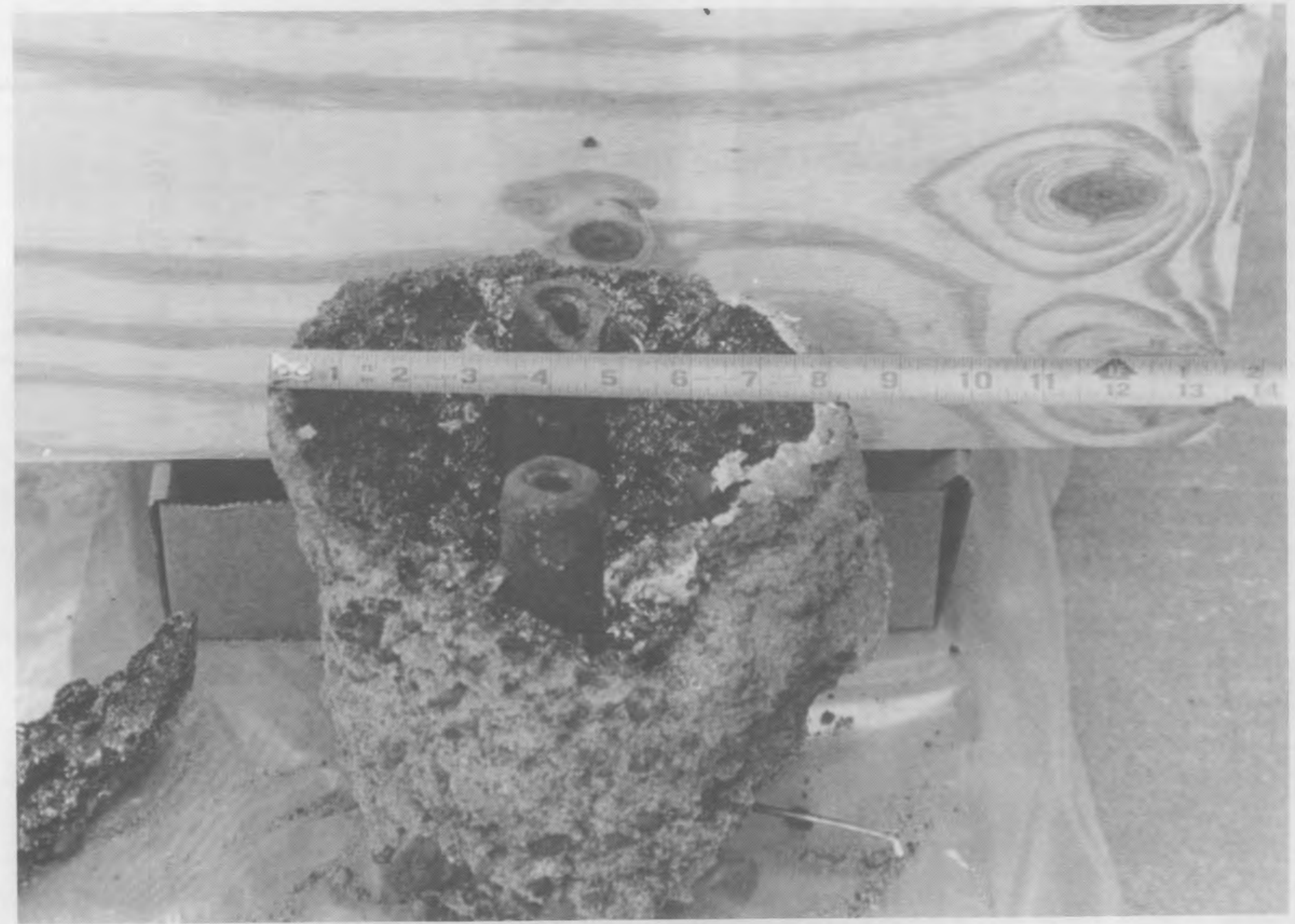

FIGURE 10. AEDC Site 1 Vitrified Block (8803810-17CN) 


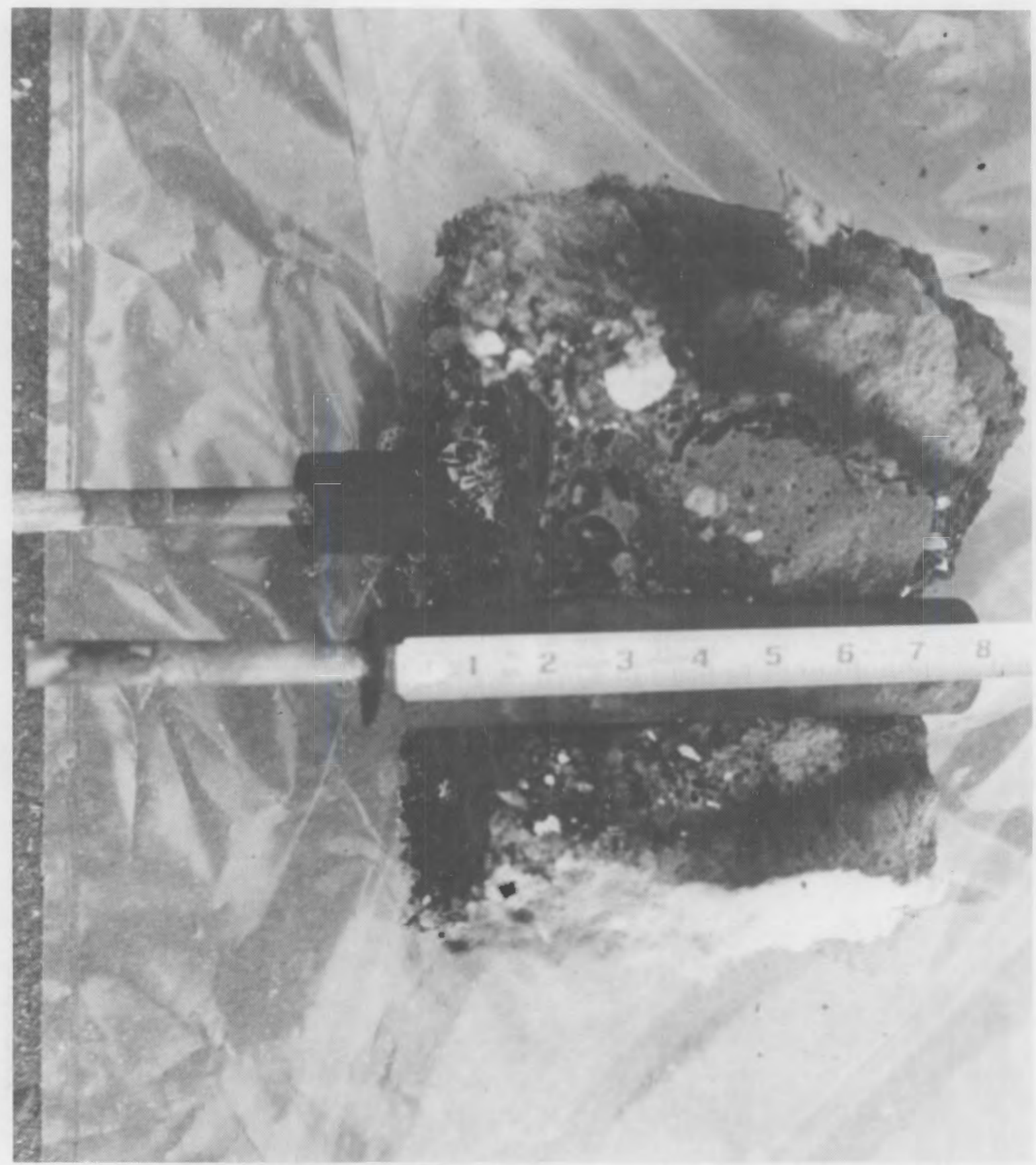

FIGURE 11. AEDC Site 10 Vitrified Block (8803779-22CN) 


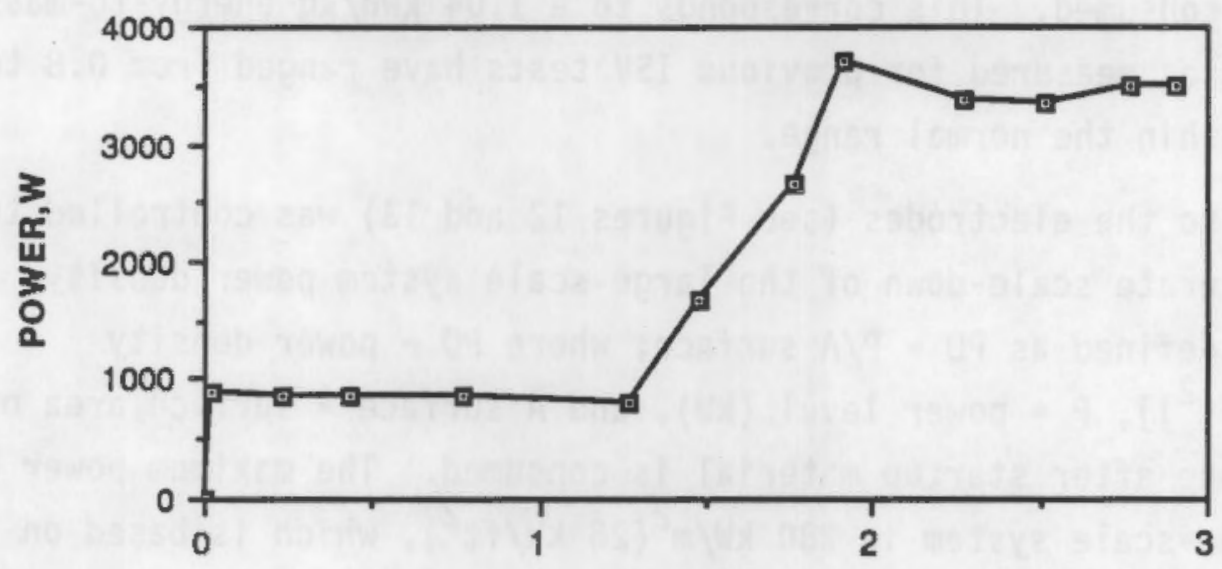

RUNTIME, hr

FIGURE 12. Power Performance Plot of the AEDC Site 1 ISV Test

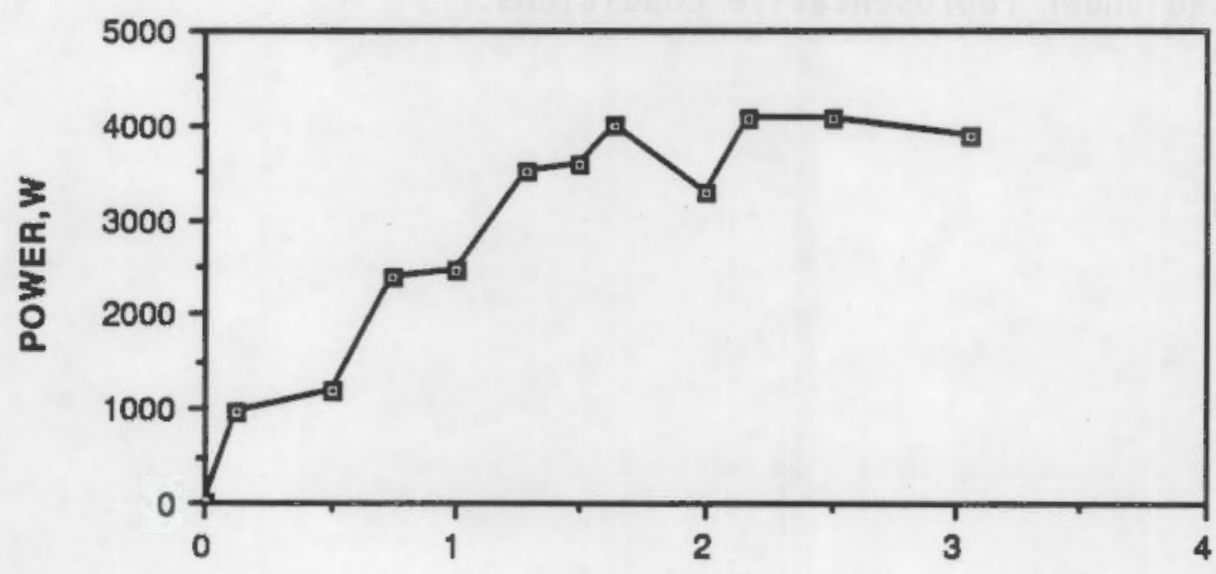

RUNTIME,hr

FIGURE 13. Power Performance Plot of the AEDC Site 10 ISV Test 
energy was consumed. This corresponds to a $1.04 \mathrm{kWh} / \mathrm{kg}$ energy-to-mass ratio. Typical ratios measured for previous ISV tests have ranged from 0.8 to 1.1 , which is within the normal range.

Power to the electrodes (see Figures 12 and 13) was controlled to provide an accurate scale-down of the large-scale system power density. Power density is defined as $P D=P / A$ surface; where $P D=$ power density $\left[\mathrm{kW} / \mathrm{m}^{2}\left(\mathrm{~kW} / \mathrm{ft}^{2}\right)\right], P=$ power level $(\mathrm{kW})$, and $A$ surface $=$ surface area of vitrification zone after startup material is consumed. The maximum power density of the large-scale system is $280 \mathrm{~kW} / \mathrm{m}^{2}\left(26 \mathrm{~kW} / \mathrm{ft}^{2}\right)$, which is based on a 3750 $\mathrm{kW}$ power supply and a minimum surface area between the electrodes of $13.4 \mathrm{~m}^{2}$ $\left(144 \mathrm{ft}^{2}\right)$. Near the end of each test, the power level was about $3 \mathrm{~kW}$ and surface area was $103.2 \mathrm{~cm}^{2}\left(16 \mathrm{in}^{2}\right)$ [10.16-cm (4-in.) wide $\times 10.16 \mathrm{~cm}$ (4 in.) electrode separation] for a power density of $291 \mathrm{~kW} / \mathrm{m}^{2}\left(27 \mathrm{~kW} / \mathrm{ft}^{2}\right)$. This is within acceptable power density limits to confirm that these tests were operated under representative conditions. 


\section{TEST RESULTS}

Since the Site 1 test was performed on clean surface soil from the Arnold site, most of the test results section concentrates on the determination of ISV processing feasibility for the Site 10 contaminated soil. Each test included analyses of the off-gas emissions for release information, the surrounding soil for migration effects, and the vitrified block for specific inorganic material retention. The processing of the Site 1 soil determined the ability of ISV to process that soil type using a sodium additive. All analytical data from the Site 10 test support the feasibility of processing the organic-contaminated soil with a fluxing addition by ISV in conjunction with a wet scrubbing and filtration off-gas treatment system.

Each bench-scale ISV test was performed over a 3-hour period to achieve a depth of $20.3 \mathrm{~cm}$ ( 8 in.). The Site 1 block weighed $6.8 \mathrm{~kg}$ (15 1b); the Site 10 block weighed $9.1 \mathrm{~kg}(20 \mathrm{lb})$. Interior views of the Site 1 and Site 10 blocks are shown in Figures 14 and 15, respectively. The increased power levels during Site 10 operations caused the Site 10 block to be larger for the same operating period.

off-gas sampling (see Figure 9) provides an indication of the amount of inorganic and organic releases during processing. The particulate components released during the tests were entrained on the filters as particulates. The elements that were collected on the filters are provided in Table 2. This table of inorganic releases shows both tests had similar quantitative particulate elemental releases. These releases are in the same range as prior testing with other soils (Buelt et al. 1987). The Site 10 data show minor concentrations of copper, nickel, lead, and zinc that were not detected in the Site 1 tests. These heavy metals are indicated as being present at Site 10 in small concentrations by the CH2M Hill data provided in Appendix B. The release quantity is not significant for any of the elements listed in Table 2. 


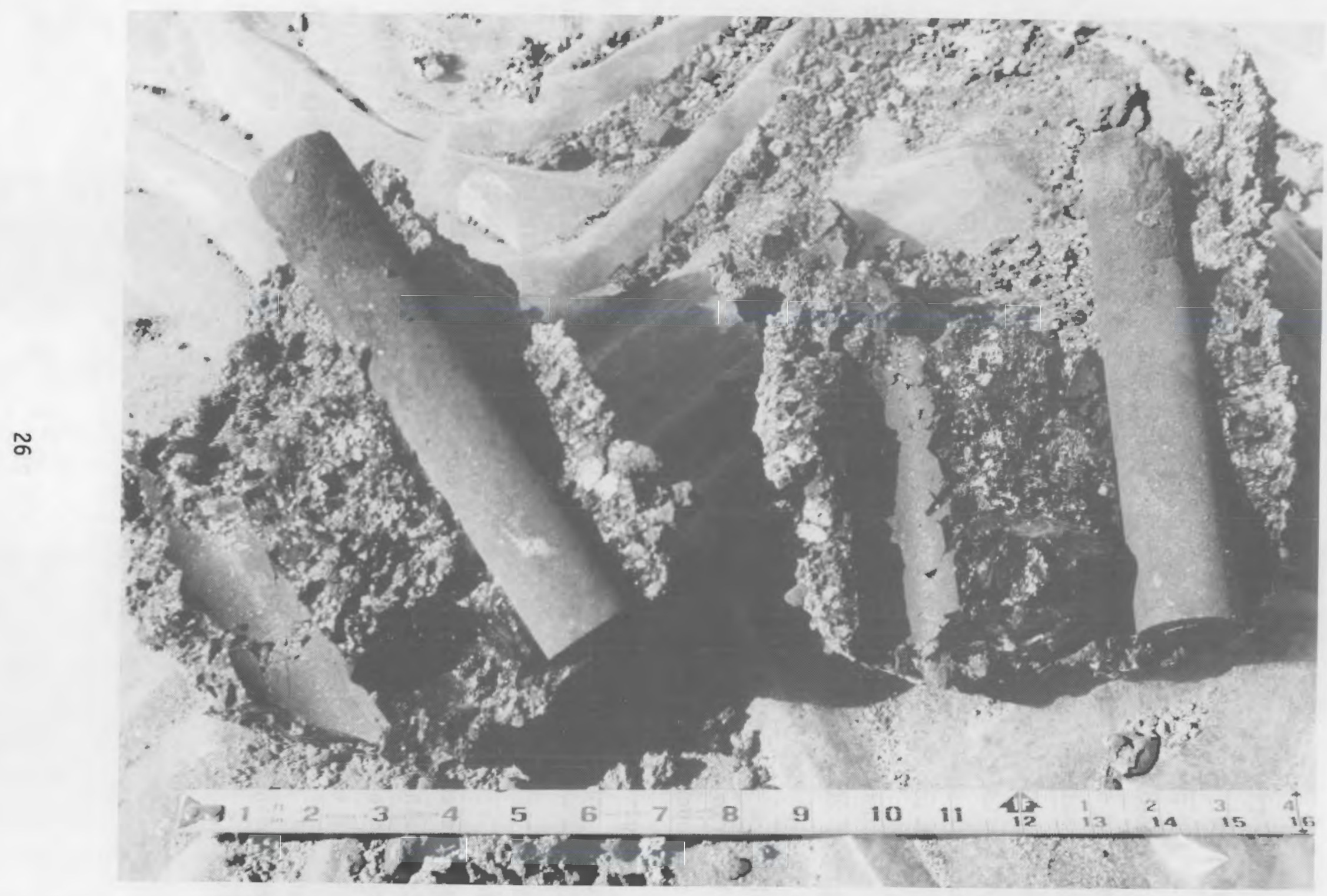

FIGURE 14. Interior View of AEDC Site 1 Vitrified Block (8803779-29CN) 


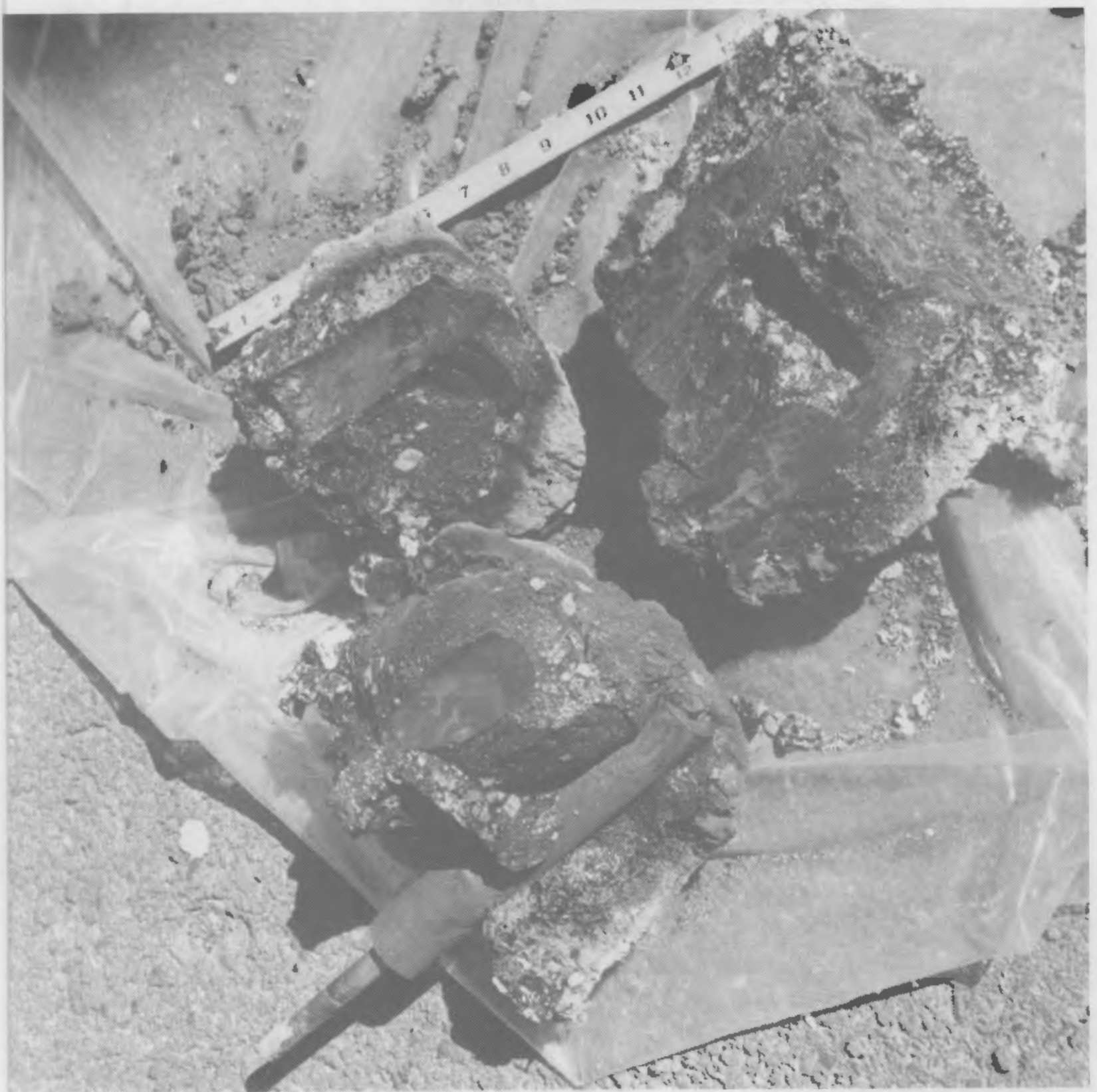

FIGURE 15. Interior View of AEDC Site 10 Vitrified Block (8803779-28CN) 
TABLE 2. Particulate Releases from the AEDC Site 1 and Site 10 ISV Tests

\begin{tabular}{|c|c|c|}
\hline \multirow[b]{2}{*}{ Component } & \multicolumn{2}{|c|}{$\begin{array}{l}\text { Filter } \\
\text { Concentration, } \\
\mu \mathrm{g} / \mathrm{cm}^{2}\end{array}$} \\
\hline & Site 1 & Site 10 \\
\hline Al & 46 & 26 \\
\hline B & 57 & 80 \\
\hline $\mathrm{Ca}$ & 123 & 60 \\
\hline $\mathrm{Cu}$ & -- & 2 \\
\hline $\mathrm{Fe}$ & 7 & 6 \\
\hline $\mathrm{Li}$ & 7 & 7 \\
\hline $\mathrm{Mg}$ & 7 & 7 \\
\hline $\mathrm{Mn}$ & 1 & 2 \\
\hline Mo & 132 & 51 \\
\hline $\mathrm{Na}$ & 288 & 528 \\
\hline $\mathrm{Ni}$ & -- & 8 \\
\hline$P$ & 47 & -- \\
\hline $\mathrm{Pb}$ & -- & 36 \\
\hline Si & 310 & 275 \\
\hline Sr & 1 & 1 \\
\hline $\mathrm{Ti}$ & 5 & 3 \\
\hline $\mathrm{Zn}$ & -- & 23 \\
\hline $\mathrm{Zr}$ & 3 & 2 \\
\hline
\end{tabular}

Primary analyses associated with the Site 10 test were directed toward organic determinations. Total organic carbon (TOC) analyses proved to be indeterminant for organic detection and migration, since the Arnold soils naturally contain $4 \%$ to $6 \%$ TOC.

The primary contaminant at Site 10 is believed to be fuel oil or hydrocarbons; therefore, the hydrocarbon analyses were used to determine ISV destruction effectiveness and migration to the surrounding soil. Analytical procedures used for the analysis of soil and water samples were similar to 
EPA Method 3500. Hydrocarbon contaminants were extracted from the samples with methylene chloride. Quantitation was performed using a gas chromatograph with flame ionization detector (GC/FID). Results for the contaminated soil were between $0.68 \%$ to $0.81 \%$ hydrocarbon level, while the surrounding clean soil was below detection level (<1 ppm).

The contaminated zone that was vitrified measured $22.9 \mathrm{~cm}(9 \mathrm{in}$.$) in$ diameter by $10.16 \mathrm{~cm}(4 \mathrm{in}$.) deep. At the $1.6 \mathrm{~g} / \mathrm{cc}$ density measured for the Site 10 contaminated soil, this corresponds to $6.7 \mathrm{~kg}$ of contaminated soil with a $0.68 \%$ to $0.81 \%$ hydrocarbon content. To determine the extent of organic migration and processing destruction of the hydrocarbons, samples of the surrounding soil and the off gas, respectively, were taken and analyzed. The samples that were taken from the surrounding soil adjacent to the block out to ambient temperature conditions showed below detection limit or low ppm quantities (0-20 ppm) of hydrocarbons. Charcoal adsorption tubes were used to collect organic off-gas samples from the two AEDC ISV tests. The samples were analyzed by GC/FID and gas chromatograph/mass spectrometry (GC/MS). The sample tubes were desorbed using carbon disulfide following the procedure of White et al. (1970). Quantitative analysis was performed by GC/FID using the internal standard method. Characterization of specific organics identified was performed by GC/MS. The results of these analyses are presented in Table 3 for both Site 1 and Site 10.

Table 3 indicates that significantly more hydrocarbons were released during the Site 10 test. This is to be expected since the Site 1 test was with clean soil. The hydrocarbon releases also show much higher quantities of more complex ( $\mathrm{C} 12$ and higher) hydrocarbons released during the Site 10 test. Again, this is consistent with the fuel oils present in the Site 10 soils. Since little or no migration of the hydrocarbons was detected to the surrounding soil, the off-gas releases can be used to determine the destruction efficiency of the ISV process on the Site 10 organic contaminants. Total hydrocarbon release was $6.24 \mathrm{mg}$ for the off-gas sample tube. The offgas flow was 60 times the sample flow; therefore, $374 \mathrm{mg}$ of hydrocarbons were released to the off-gas system. Comparing this release to the total hydrocarbons initially present in the contaminated soil indicated that $0.7 \%$ to $0.8 \%$ of the hydrocarbons were released to the off-gas system and not 
IABLE 3. AEDC Site 1 and Site 10 Organic Off-Gas Analyses

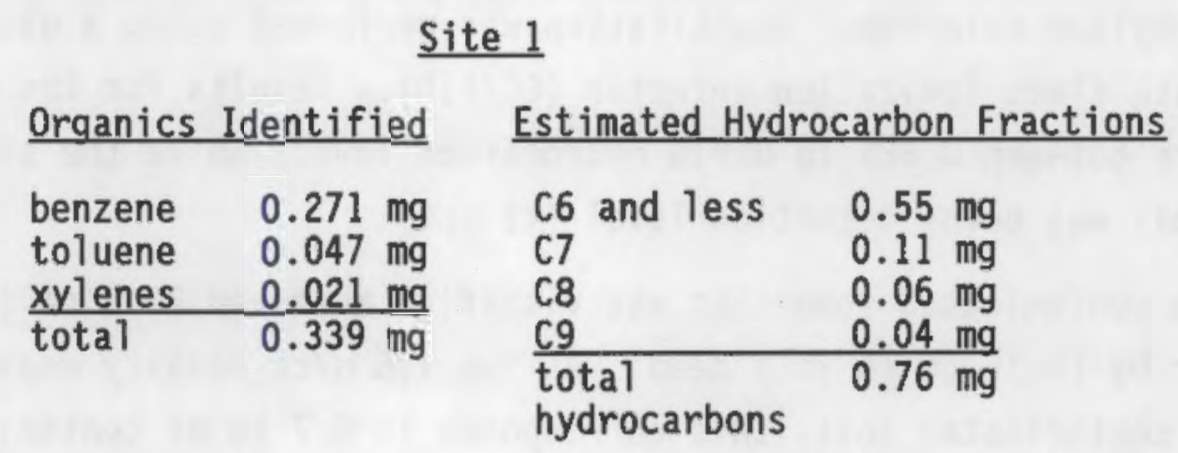

\section{SITE 10}

Organics Identified Estimated Hydrocarbon Fractions

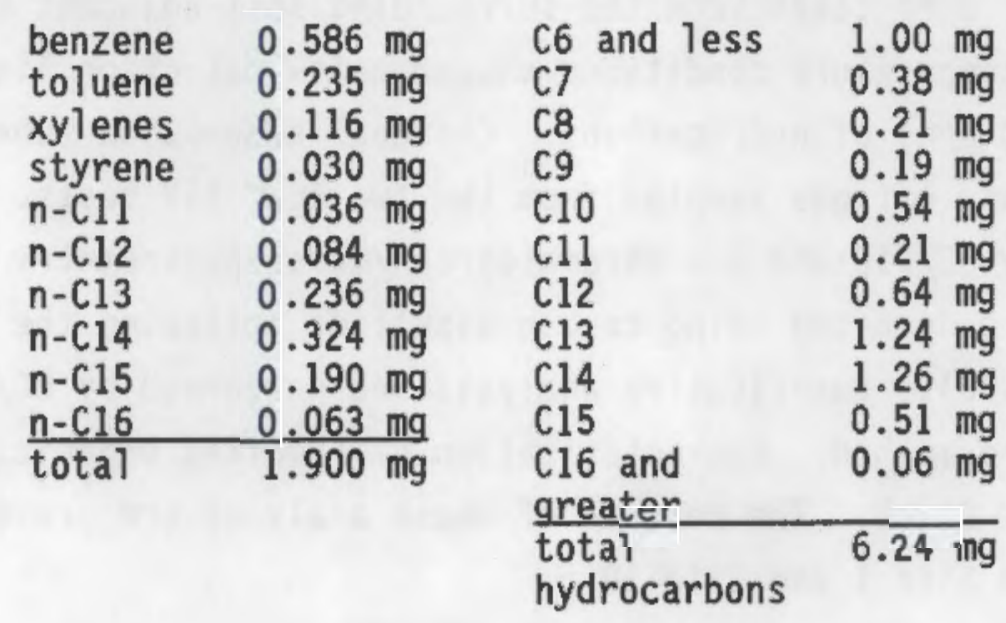

destroyed. Considering a $20 \mathrm{ppm}$ "worst case" concentration in the surrounding soil, this lowers the ISV process destruction efficiency to $98.1 \%$. The high destruction efficiency illustrates the feasibility of applying ISV to the fire training pit area at the AEDC Site 10. 


\section{LEACH TESTING}

This section reports the results of the Extraction Procedure (EP) Toxicity and Toxic Characteristics Leach Procedure (TCLP) performed on the Site 1 and Site 10 vitrified materials. Table 4 lists the metals of concern, their maximum concentration limit, and the results of the EP Toxicity and TCLP tests on a per sample and product average basis. The concentrations of all metals listed are below the maximum permissible limits specified; therefore, the vitrified materials from each site passed both leach tests. The leaching information indicates that the residual ISV product would not be listed as a hazardous material after the processing had destroyed the organic content, which should allow release of the site as containing nonhazardous material under regulatory criteria. 
TABLE 4. EP Toxicity and TCLP Results for the ISV Product EP Toxicity Results, ppm

\begin{tabular}{|c|c|c|c|c|c|c|c|c|c|}
\hline $\begin{array}{l}\text { EP Tox. } \\
\text { Metals }\end{array}$ & $\begin{array}{l}\text { Conc. } \\
\text { ppm }\end{array}$ & & & & Ave. & & & & Ave. \\
\hline As & 5 & $<0.1$ & $<0.1$ & $<0.1$ & $<0.1$ & $<0.1$ & $<0.1$ & $<0.1$ & $<0.1$ \\
\hline $\mathrm{Ba}$ & 100 & 0.004 & 0.005 & 0.006 & 0.005 & 0.037 & 0.036 & 0.056 & 0.043 \\
\hline $\mathrm{Cd}$ & 1 & $<0.004$ & $<0.004$ & $<0.004$ & $<0.004$ & $<0.004$ & $<0.004$ & $<0.004$ & $<0.004$ \\
\hline $\mathrm{Cr}$ & 5 & $<0.02$ & $<0.02$ & $<0.02$ & $<0.02$ & $<0.02$ & $<0.02$ & $<0.02$ & $<0.02$ \\
\hline $\mathrm{Pb}$ & 5 & $<0.1$ & $<0.1$ & $<0.1$ & $<0.1$ & $<0.1$ & $<0.1$ & $<0.1$ & $<0.1$ \\
\hline $\mathrm{Hg}$ & 0.2 & $<0.001$ & $<0.001$ & $<0.001$ & $<0.001$ & $<0.001$ & $<0.001$ & $<0.001$ & $<0.001$ \\
\hline $\mathrm{Se}$ & 1 & $<0.01$ & $<0.01$ & $<0.01$ & $<0.01$ & $<0.01$ & $<0.01$ & $<0.01$ & $<0.01$ \\
\hline $\mathrm{Ag}$ & 5 & $<0.1$ & $<0.1$ & $<0.1$ & $<0.1$ & $<0.1$ & $<0.1$ & $<0.1$ & $<0.1$ \\
\hline
\end{tabular}

TCLP Results, ppm

Max.

EP Tox. Conc.

Metals

As

$\mathrm{Ba}$

Cd

$\mathrm{Cr}$

$\mathrm{Pb}$

$\mathrm{Hg}$

Se

$\mathrm{Ag}$

T1

$\mathrm{Ni}$

ppm

Site 1

\section{Site 1}

Site 1

Site 10

\begin{tabular}{|c|c|c|c|c|c|}
\hline & & Ave. & & & Ave. \\
\hline$<0.1$ & $<0.1$ & $<0.1$ & $<0.1$ & $<0.1$ & $<0.1$ \\
\hline 0.026 & 0.019 & 0.023 & 0.067 & 0.079 & 0.073 \\
\hline$<0.004$ & $<0.004$ & $<0.004$ & $<0.004$ & $<0.004$ & $<0.004$ \\
\hline 0.026 & 0.030 & 0.028 & 0.039 & 0.043 & 0.041 \\
\hline 0.300 & $<0.1$ & 0.200 & $<0.1$ & $<0.1$ & $<0.1$ \\
\hline$<0.001$ & $<0.001$ & $<0.001$ & $<0.001$ & $<0.001$ & $<0.001$ \\
\hline$<0.01$ & $<0.01$ & $<0.01$ & $<0.01$ & $<0.01$ & $<0.01$ \\
\hline$<0.1$ & $<0.1$ & $<0.1$ & $<0.1$ & $<0.1$ & $<0.1$ \\
\hline$<0.01$ & $<0.01$ & $<0.01$ & $<0.01$ & $<0.01$ & $<0.01$ \\
\hline 0.232 & 0.144 & 0.188 & 0.280 & 0.477 & 0.379 \\
\hline
\end{tabular}

(a) EPA has not established limits. $\mathrm{Tl}$ and $\mathrm{Ni}$ are proposed to be added to TCLP list. Good rule of thumb for limit determination is $100 \mathrm{x}$ drinking water standards. 


\section{REFERENCES}

Buelt, J. L., and J. G. Carter. 1986. In Situ Vitrification Large-Scale Operational Acceptance Test Analysis. PNL-5828, Pacific Northwest Laboratory, Richland, Washington.

Buelt, J. L., C. L. Timmerman, K. H. Oma, V. F. FitzPatrick, and J. G. Carter. 1987. In Situ Vitrification of Transuranic Waste: An Updated Systems Evaluation and Applications Assessment. PNL-4800 Suppl. 1, Pacific Northwest Laboratory, Richland, Washington.

Carter, J. G., S. 0. Bates, and G. 0. Maupin. 1987. In Situ Vitrification of Oak Ridge National Laboratory Soil and Limestone. PNL-6174, Pacific Northwest Laboratory, Richland, Washington.

Oma, K. H., D. R. Brown, J. L. Buelt, V. F. FitzPatrick, K. A. Hawley, G. B. Mellinger, B. A. Napier, D. J. Silviera, S. L. Stein, and C. L. Timmerman. 1983. In Situ Vitrification of Transuranic Wastes: Systems Evaluations and Applications Assessment. PNL-4B00, Pacific Northwest Laboratory, Richland, Washington.

Timmerman, C. L., R. A. Brouns, J. L. Buelt, and K.H. Oma. 1983. "In Situ Vitrification: Pilot-Scale Development." Nuclear and Chemical Waste Management $4: 267$.

Timmerman, C. L. and K. H. Oma. 1984. An In Situ Vitrification Pilot-Scale Radioactive Test. PNL-5240, Pacific Northwest Laboratory, Richland, Washington.

White, L. D., D. G. Taylor, P. A. Mauer, and R. E. Kupel. 1970. American Industrial Hygiene Association Journal 31:225. 



\section{APPENDIX A}

\section{AEDC SITE 1 AND SITE 10 SOIL ANALYSIS}


TABLE A-1. AEDC Site 1 and Site 10 Sample Identification and Location Site 1 Samples

\begin{tabular}{|c|c|}
\hline Identification & Location \\
\hline AS-1-1 & Test soil Site 1 \\
\hline AS-1-2 & Borrow pit soil - southeast of landfill Site 1 \\
\hline AS-1-3 & Surface soil by SL-4 well southwest of landfill site \\
\hline AS-1-4 & South landfill - southeast region surface \\
\hline AS-1-5 & South landfill - southeast region surface \\
\hline AS-1-6 & North landfil1 - northeast region surface \\
\hline AS-1-7 & North landfill - northwest region surface \\
\hline AS $-1-8$ & North landfill - central subsurface borings \\
\hline AS-1-9 & $\begin{array}{l}\text { Leach pit region - south of landfill Site } 1 \text { limestone rock } \\
\text { area }\end{array}$ \\
\hline & Site 10 Samples. \\
\hline Identification & Location \\
\hline AS-10-1 & Test sludge \\
\hline AS-10-2 & Test clean soil \\
\hline AS $-10-3$ & Upper burn pit - left wing of mock airplane \\
\hline AS-10-4 & Lower overflow pond - east side \\
\hline AS-10-5 & Lower overflow pond - west side \\
\hline AS-10-6 & Clean soil - surface clay \\
\hline AS-10-7 & Clean soil - subsurface layer \\
\hline AS- $10-8$ & Run-off area surface soil \\
\hline AS-10-9 & Subsurface soil - east coffer \\
\hline
\end{tabular}


TABLE A-2. AEDC Site 1 Sample Analyses, wt\%

\begin{tabular}{|c|c|c|c|c|c|c|c|c|c|}
\hline Oxide & AS-1-1 & AS-1-2 & AS $-1-3$ & AS-1-4 & AS-1-5 & AS $-1-6$ & AS $-1-7$ & AS $-1-8$ & $A S-1-9$ \\
\hline $\mathrm{Al}_{2} \mathrm{O}_{3}$ & 11.2 & 10.5 & 8.19 & 7.69 & 6.52 & 9.72 & 8.31 & 6.98 & 6.24 \\
\hline $\mathrm{BaO}$ & 0.010 & 0.011 & 0.017 & 0.007 & 0.013 & 0.012 & 0.012 & 0.013 & 0.020 \\
\hline $\mathrm{CaO}$ & 0.22 & $<0.02$ & 0.28 & 0.30 & 2.23 & 1.52 & 1.00 & 3.27 & 0.91 \\
\hline $\mathrm{Fe}_{2} \mathrm{O}_{3}$ & 6.21 & 5.67 & 5.08 & 14.1 & 3.04 & 5.45 & 5.09 & 3.57 & 3.24 \\
\hline $\mathrm{K}_{2} \mathrm{O}$ & $(0.29)^{(a)}$ & $(0.27)^{(a)}$ & 0.54 & $(0.19)^{(a)}$ & 0.56 & $(0.35)^{(a)}$ & 0.36 & 0.62 & 0.60 \\
\hline $\mathrm{MgO}$ & 0.281 & 0.294 & 0.273 & 0.215 & 0.377 & 0.341 & 0.398 & 1.22 & 0.46 \\
\hline $\mathrm{MnO}_{2}$ & $\cdots$ & 0.008 & -- & -- & $\cdots$ & $\cdots$ & -- & 0.008 & 0.023 \\
\hline $\mathrm{Na}_{2} \mathrm{O}$ & 0.29 & 0.28 & 0.39 & 0.34 & 0.32 & 0.24 & 0.26 & 0.31 & 0.38 \\
\hline $\mathrm{NiO}$ & 0.041 & 0.055 & 0.063 & 0.028 & 0.032 & 0.037 & 0.045 & 0.037 & 0.065 \\
\hline $\mathrm{SiO}_{2}$ & 71.5 & 72.7 & 75.1 & 66.8 & 67.3 & 73.1 & 71.3 & 72.0 & 78.8 \\
\hline Sro & -. & 0.006 & 0.007 & -. & $\therefore$ & 0.008 & 0.008 & 0.010 & 0.008 \\
\hline $\mathrm{riO}_{2}$ & 1.07 & 1.12 & 0.939 & 0.816 & 0.636 & 1.13 & 1.07 & 0.733 & 1.09 \\
\hline $\mathrm{ZrO}_{2}$ & 0.055 & 0.052 & 0.057 & 0.027 & 0.115 & 0.059 & 0.086 & 0.041 & 0.085 \\
\hline $\begin{array}{l}\text { Total } \\
\text { Oxide }\end{array}$ & 90.9 & 90.7 & 90.5 & 90.3 & 80.7 & 91.8 & 87.9 & 88.4 & 91.9 \\
\hline $\begin{array}{l}\text { Moisture } \\
\text { Content }\end{array}$ & 19.3 & 13.5 & 14.6 & 6.36 & 7.67 & 10.9 & 11.0 & 15.0 & 16.9 \\
\hline
\end{tabular}

(a) Near detection limit. 
IABLE A-2. AEDC Site 10 Sample Analyses, wt\%

\begin{tabular}{|c|c|c|c|c|c|c|c|c|c|}
\hline Oxide & AS-10-1 & AS-10-2 & AS-10-3 & AS-10-4 & AS-10-5 & AS-10-6 & AS-10-7 & AS-10-8 & AS-10-9 \\
\hline $\mathrm{Al}_{2} \mathrm{O}_{3}$ & 6.25 & 10.4 & 3.39 & 5.31 & 4.80 & 9.08 & 11.4 & 9.51 & 5.77 \\
\hline $\mathrm{BaO}$ & 0.022 & 0.044 & 0.024 & 0.012 & 0.013 & 0.019 & 0.059 & 0.020 & 0.017 \\
\hline $\mathrm{CaO}$ & 5.53 & 5.21 & 33.5 & 5.84 & 23.7 & 0.92 & 5.82 & 2.55 & 1.08 \\
\hline $\mathrm{Cr}_{2} \mathrm{O}_{3}$ & 0.028 & 0.031 & -- & -- & -. & - & 0.042 & 0.033 & -- \\
\hline CuO & 0.013 & 0.014 & $\cdots$ & $\cdots$ & -- & -- & 0.045 & 0.014 & $\ldots$ \\
\hline $\mathrm{Fe}_{2} \mathrm{O}_{3}$ & 3.78 & 4.99 & 2.87 & 2.75 & 2.57 & 4.87 & 7.11 & 5.35 & 2.67 \\
\hline $\mathrm{K}_{2} \mathrm{O}$ & 0.51 & 1.05 & 0.46 & 0.46 & 0.47 & 0.47 & 1.25 & 0.74 & 0.40 \\
\hline $\mathrm{MgO}$ & 0.435 & 0.534 & 1.56 & 0.426 & 0.855 & 0.358 & 0.614 & 0.508 & 0.297 \\
\hline $\mathrm{MnO}_{2}$ & 0.016 & 0.020 & 0.015 & - & 0.013 & 0.012 & 0.031 & 0.044 & -- \\
\hline $\mathrm{Na}_{2} \mathrm{O}$ & 0.29 & 0.33 & 0.24 & 0.30 & 0.22 & 0.26 & 0.36 & 0.26 & 0.28 \\
\hline NiO & 0.034 & 0.041 & 0.041 & 0.028 & 0.033 & 0.029 & 0.065 & 0.047 & 0.034 \\
\hline $\mathrm{SiO}_{2}$ & 70.7 & 63.4 & 28.2 & 73.3 & 43.9 & 72.5 & 53.2 & 71.7 & 77.6 \\
\hline Sro & 0.012 & 0.057 & 0.036 & - & 0.023 & 0.019 & 0.083 & 0.015 & 0.007 \\
\hline $\mathrm{TiO}_{2}$ & 0.984 & 0.865 & 0.423 & 0.941 & 0.587 & 1.13 & 0.739 & 0.780 & 1.15 \\
\hline $\mathrm{ZrO}_{2}$ & 0.061 & 0.046 & 0.018 & 0.064 & 0.022 & 0.029 & 0.046 & 0.087 & 0.121 \\
\hline $\begin{array}{l}\text { Total } \\
\text { Oxide }\end{array}$ & 88.7 & 87.1 & 70.8 & 89.4 & 77.1 & 89.1 & 80.8 & 91.6 & 87.5 \\
\hline $\begin{array}{l}\text { Moisture } \\
\text { Content }\end{array}$ & 20.4 & 16.4 & 14.3 & 28.3 & 24.2 & 13.8 & 18.4 & 15.8 & 30.4 \\
\hline
\end{tabular}





\section{APPENDIX B}

CH2M HILL AEDC SITE 10 DATA 


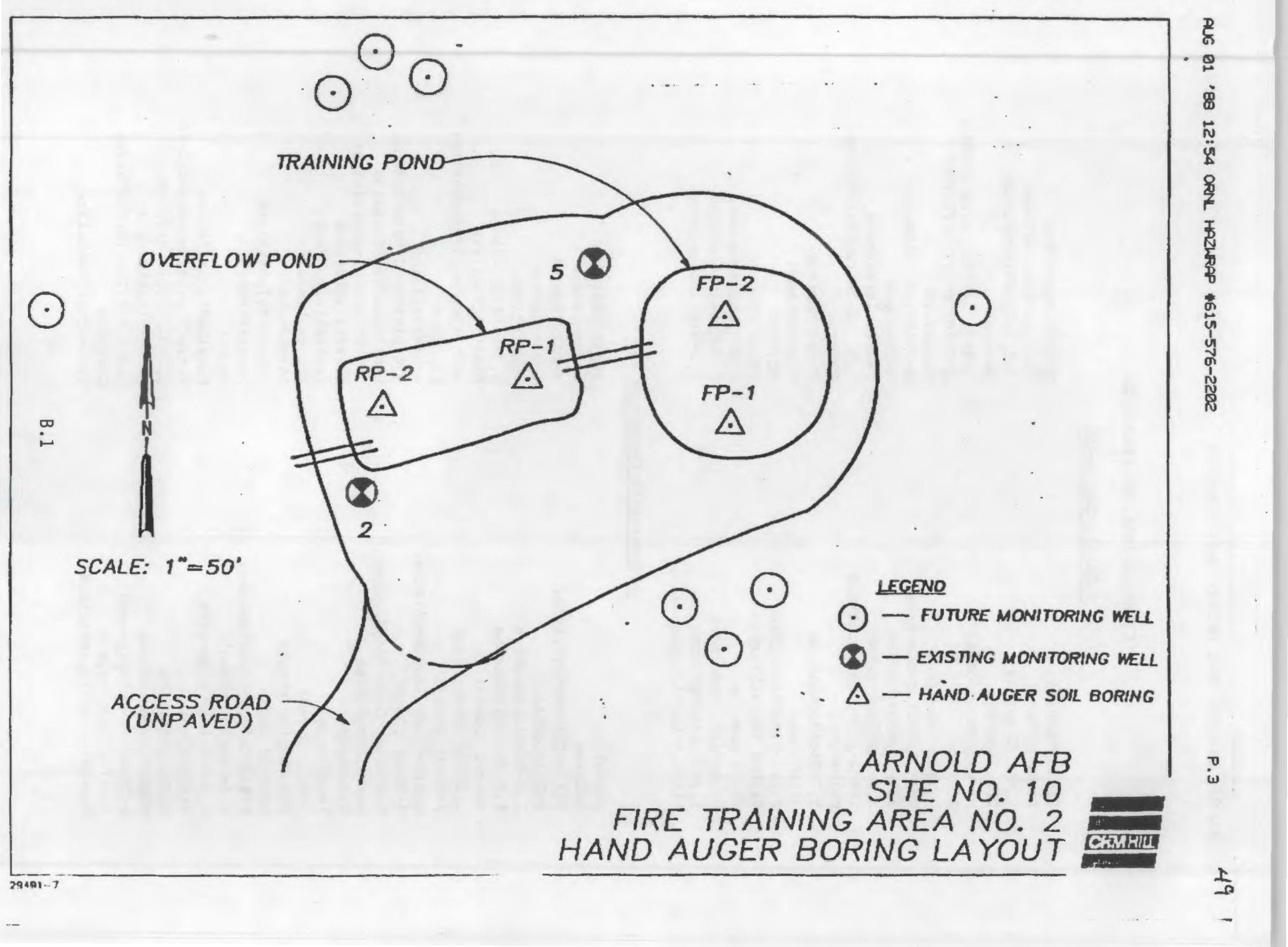




\section{CHEMICAL ANALYSES PERFORMBD}

\section{Volatile Compounds}

Chloromethane

Bromome thane

Vinyl Chloride

Chloroethane

Methylene Chloride

icetone

Carbon Dirulfide

Trichlorofluorome thane

1,1-D1chloroethene

1,1-Dichloroethare

Trand-1,2-Dichloroethane

Chloroform

1,2-Dichloroethane

2mButanone

1,1,1-Tr1chloroethane

Carbon Tetrachloride

Vinyl Acetate

Bromodlehloreme thane

1, 2-Dichloropropane

c18-1,3-Dichloropropone
Tricholoroethene

Dibromochlorome thene

1,1,2-Trichloroethane

Benzene

trans-1, 3-Dichloropropene

2-Chloroe thylvinyle ther

Bromoform

4-Methyl-2-Pentanone

2-Hexanone

Tetrachloroe thene

1,1,2,2-Tetrachioroe thane

Toluene

Chlorobenzene

Ethylbenzene

Styrene

Total Xylenes

1,3-Dichlorobenzere

1,4-D1 chlorobanzene

1, 2-Dichlorobenzene

Semfvolatile Compounde

Phenol

Anilino

b1 (2-Chloroothy 1) Ether

2-Chlorophenol

1,3-Dichlorobenzene

1,4-Dichlorobenzene

- Benzyl Alcohol

1,2-Dichlorobenzene

2-Methyl phenol

bis (2-Ch loroisopropyl) Ether

4-Methyl phenol

N-Nitroso-Di-n-Propylamine

Hexachloroe thane

Nit trobenzene

Inophorone

2-Nitrophenol

2,4-Dime thy lphenol

Benzole acid

b1 (2-Chloroe thoxy) Methane

2,4-Dichlorophenol

$1,2,4-$ Trichlorobenzene

Naphthalene

4-Chlcroaniline

Hexachlorobutadione

4-Chloro-3-Methyl phenol

2-Methy lnaphthalene

Hexachlorocyclopentadiene
3-Nitroaniline

Aconaph thene

4-Nitrophenol

4-N1 trophenol

Dibenzofuran

2,4-Dinitrotoluene

Dlethyl Phtalate

4-Chloropheny1-phenylether

Fluorene

4-Nitroaniline

4,6-Dinitro-2-Methylphenol-

$N-N i$ trosodiphenylamine

4-Bromophenyl-phenyle ther

Hexachlorobenzene

Pentachlorophenol

Phenanthrene

Anthracene

Di-n-Butylphthalate

Fluorantheno

Pyrene

Butylbenzylphthalate

Te trachlorodibenzo-p-dioxin

3, 3-D1chlorobenzidine

Benzo (a) Anthracene

bie (2-Ethylhexy 1) Phthalate

Chrysene

Di-n-Octyl Phthalate 


\section{Sumivolatile Compounds - (continued)}

2, 4,6-Trichlorophenol

2,4,5-Trichlorophenol

2-Chloronaphthalen

2-N1troanlilne

Dimethyl Phthalate

Acenaphthyleno

2,6-Din1trotoluene
Benzo (b) Fluoran thene

Benzo (k) Fluoran thene

Benzo (a) Pyrene

Indeno (1, 2, 3-cd) Pyrone

Dibenz $(a, h)$ Anthracene

Benzo $(q, h, i)$ Perylene

Pest1e1de / PCB Compounds

alpha-BHC

beta-BHC

dalta-BHC

ganma-BHC (Lindane)

Hepeachlor

Aldrin

Heptachlor Expoxide

Bndosulfan I

Dieldrin

4, 4'-DoE

Endrin

Endosulfan II

4, 4' $-D D D$

Endosulfan Sulfate

4,4'-DDT

Methoxychlor

Endrin Ketone

Chlordane

Toxaphene

Aroclor-1016

Aroelor-1221

, Aroclor-1232

Aroclor-1242

Aroclor -1248

Aroclor-1254

Aroclor-1260

Metals

Silver

Areenic

Beryllium

Cadinitum

Cyanide, Distilled

Chromium

Copper

Mercury

Nickel

Lead

Ant1mony

Solenium

Thallium

zinc 


\begin{tabular}{|c|c|c|c|}
\hline LOCATIOW & $\begin{array}{l}\text { DEPTH } \\
\text { (ft) }\end{array}$ & conpoutio & $\begin{array}{r}\text { cowcentretion } \\
\text { coskes }\end{array}$ \\
\hline & $\boldsymbol{1}$ & OIE(2-ETKTLHEXYL)PKTMALATE & 310 \\
\hline$p 0-11$ & is & arocion-1254 & 600 \\
\hline Fp.13 & $r$ & DIS(2-ETHYKEXTL)PHTKULATE & 2000 \\
\hline $\mathbf{m P 0} \mathbf{\{ 3}$ & 7 & AlOCLOA. 1254 & so \\
\hline$\therefore$ FP-21 & 11 & PHERAMT TREELE & 6100 \\
\hline PP-21 & 11 & PLOCRMTMENE & 11000 \\
\hline FP-21 & 11 & PYRENE & 3500 \\
\hline FP-21 & I" & CHN2O(A)NATMRACEME & 2000 \\
\hline FP-21 & 11 & Its(2-ETHYMEXTL) PNTKMLATE & 1600 \\
\hline $8 P-21$ & 10 & CHAYSEME & 2000 \\
\hline$(P-21)$ & 11 & IEN20(B)FLUORMUTHENE & 2200 \\
\hline Pp-2i & II & DENZO(A)PYREKE & 1300 \\
\hline FP-21 & 10 & IMDEMD(1,2,3-Co)PFRENE & 1100 \\
\hline $\mathbf{P e - 2 1}$ & 11 & EEMZO(O, H, I) PERTLERE & 1100 \\
\hline$F P-21$ & "1" & AROCLOH-123G & 4300 \\
\hline pe-22 & 41 & OIS(2-ETKTLNEXT) ) STYULATE & 910 \\
\hline $18-22$ & 4 & MacLOR-1254 & 100 \\
\hline FP.-23 & 7 & MACLOOH-1254 & 20 \\
\hline $2 P-12$ & 41 & DIA(2-ETMTLMEXYL) & 1600 \\
\hline RP-23 & $\boldsymbol{m}$ & BIS(2-ETHYLHEXYL)SHTHALATE & 230 \\
\hline
\end{tabular}

$07 / 06 / 80$

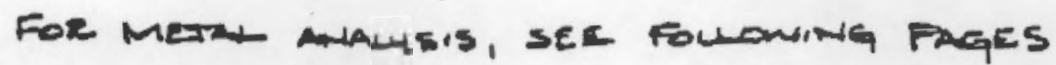


AUG O1 'B 12:55 ORNL HAZURAP *615-576-2202

F.7

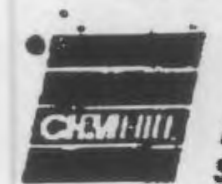

Engineers

Plannars

Economists

Scientists

INOFGANIC REFOFT DF ANALYSIS

CH2M HILL/ATL

229 FEACHTREE STREET, N.E., SUITE 300

ATLANTA, GEORGIA 30303-1602

Fage: 1
Date: 0 o/30/88

ATTN: HR. N, STRICKLAND/ATL

Frojec: Nimber: SA29491.6

Laboratory, Number: 11226

RE: Sample(s) received by CHin HILL on $0 S / 18 / 88$. ARMOLD AIK FORCE BASE.

\begin{tabular}{|c|c|c|c|c|c|c|c|c|c|}
\hline Mulyeis Daceriptian & & $\begin{array}{c}\text { FP-1: } \\
2 / 12 / 69 \\
1140 \text { conp } \\
17 .\end{array}$ & $\begin{array}{c}5 P-12 \\
5 / 12 / 88 \\
1110 \mathrm{COH} \\
4 \mathrm{FT} .\end{array}$ & & $\begin{array}{c}F P-13 \\
5 / 12 / 80 \\
1200 \text { CONP } \\
7 \mathrm{FT} .\end{array}$ & $\begin{array}{c}\text { FP-2: } \\
\text { 5/1298 } \\
1240 \text { CENP } \\
1 \text { T. }\end{array}$ & $\begin{array}{c}F P-29 \\
5 / 12 / 88 \\
1320 \text { COMP } \\
4 F .\end{array}$ & $\begin{array}{c}5 p-23 \\
5 / 12 / 88 \\
1350 \text { coup } \\
7 \pi .\end{array}$ & $\begin{array}{c}k F-11 \\
5 / 12 / E \theta \\
2445 \text { COMP } \\
1 F T .\end{array}$ \\
\hline & . & Sor. & sats & & SOIL & sorl & SOIL & SOIL & soIl \\
\hline Silver (ppb) & & (3) & 8 & & (3) & $<34^{\circ}$ & $\cos 3$ & $<3 x^{2}$ & $\left\langle 3 x^{\prime}\right.$ \\
\hline Arsenic $(p \rho b)$ & & \% & 6.41 & & 10.44 & 8.2H & $7.6 \mathrm{H}$ & 194 & \\
\hline Barylliua (ppb) & & $<0.5 H$ & $<0.5 n$ & & $<0.5 y$ & $\langle 0.5 K$ & $<0.34$ & $\langle 0.5\rangle$ & <o.: \\
\hline Cadiulus (ppo) & & $10 y$ & 104 & & 104 & 84 & 6H & 124 & $5 y$ \\
\hline Gyanida, Distilled (ppo) & & $<0.3114$ & $<0.304$ & & $<0.30 \mathrm{~K}$ & $<0.304$ & $<0.29 K$ & $<0.374$ & $<0.33 n$ \\
\hline Mraniva (ppb) & & 304 & 394 & . & 494 & $20 \mathrm{H}$ & $27 k$ & SOH & $25 \mathrm{H}$ \\
\hline Copper (ppb) & & 84 & sy & & 81 & 103K & 64 & 94 & $19 N$ \\
\hline Mireupy (ppo) & & 0.34 & O.tu & . & 0.6H & $3.7 \mathrm{~K}$ & $1.3 \mu$ & 4.3H & $0.21 x$ \\
\hline Wathel (ppo) & & र4H & 《4H & & <4र & $m$ & <4: & $\langle 4 \mathrm{X}$ & $\left\langle 4 K^{\circ}\right.$ \\
\hline Load (ppo) & & 9.84 & 5.24 & & $6.3 \mathrm{H}$ & 26.94 & 6.4H & 8.34 & $7.3 \mathrm{H}$ \\
\hline Antisony (ppp) & & 60.64 & $<0.6 \mathrm{~N}$ & & $<0.64$ & $\langle 0.8 k$ & $<0.6 \mathrm{H}$ & $<0.7 h$ & $<0,7 \mathrm{~K}$ \\
\hline Selenius (ppb) & & $<0.64$ & <0.6m & & $\ll 0.6 \mathrm{H}$ & $\langle 0,64$ & $<0.64$ & $<0.8 \mathrm{~K}$ & $\langle 0.7 H$ \\
\hline Thalllus (ppo) & & $<0.6$ & $<0.6$ & & $<0.6$ & $\$ 0.6$ & $<0.6$ & $<0.8$ & $<0.8$ \\
\hline Zine $(p p b)$ & & 15:4 & 16H & & $44 x$ & 944 & $21 \mathrm{H}$ & 224 & $42 \mathrm{H}$ \\
\hline
\end{tabular}


AUG O1 'B8 12:56 ORVL HAZWRPP *615-576-2202

P.8

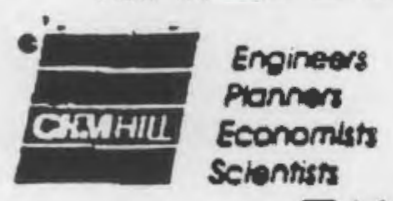

INOFGANIC FEFOFT OF ANALYSIS

CH2M HILL/ATL

229 FERCHTKEE STREET, N.E., SUITE 300

ATLANTA, GEORGIA 30303-1602.

Fage: 2

Date: $06 / 30 / 88$

ATTN: MR. N. STRICKLANO/ATL

Projece Number: SA29491.

REE: Samele(s) received by CHaH HILL or $05 / 18 / 8 \varepsilon$. AKINOLD AIR FORCE BASE

Laboratory Numbert 11226

ARINOLD AIR FORCE BASE

\begin{tabular}{|c|c|c|c|c|c|c|c|}
\hline Analysts Description & $\begin{array}{l}\text { SP-12 } \\
5 / 12 ; 88 \\
1450 \text { COHP } \\
\text { I FT. }\end{array}$ & $\begin{array}{l}R P-21 \\
5 / 12 / 88 \\
1545 \text { conP } \\
1 \mathrm{FT} .\end{array}$ & $\begin{array}{c}R P-22 \\
5 / 12 / 88 \\
1619 \text { cOKP } \\
4 \mathrm{FT} .\end{array}$ & $\begin{array}{c}\text { PP-22A } \\
3 / 12 / 88 \\
1615 \text { COMP } \\
4 \mathrm{FT} .\end{array}$ & $\begin{array}{c}R C-D \\
5 / 12 / 88 \\
16+5 \text { CORP } \\
7 \mathrm{FT} .\end{array}$ & $\begin{array}{c}\text { MS } \\
\text { MATKIX } \\
\text { SPIKE } \\
\text { I RECOUERY }\end{array}$ & $\begin{array}{c}\text { KSD } \\
\text { MATEIX } \\
\text { SPIKE } \\
\text { OUPLICATE } \\
\text { AMALYSIS } \\
\text { RPD }\end{array}$ \\
\hline & soll & soll & SOIL & SOIE & son & SOIL & SOIL \\
\hline Silvep $(p p b)$ & CNI & (3it & ४3H & \$H & षH & 98 & 3 \\
\hline Afsenic ( $p p b)$ & 6.24 & $6.7 \pi$ & 5.31 & 3.74 & 7.94 & 106 & 2 \\
\hline Berylliw (pos) & $6.5 n$ & $0.8 H$ & $<0.5 \mathrm{H}$ & $<0.5 \mathrm{H}$ & $<0.54$ & 95 & 0 \\
\hline Cadoin (ppb) & 174 & $19 \%$ & $15 \mathrm{~N}$ & 124 & $7 w$ & 84 & 0 \\
\hline Cyanide, Distilled (ppe) & 0.351 & $<0.304$ & $<0.334$ & $<0.344$ & $<0.334$ & 102 & 0 \\
\hline Chrostus (ppb) & 711 & 904 & 49\% & $37 k$ & 264 & $\%$ & 0 \\
\hline Copper (ppb) & 9 & 64 & 5n" & 4h & 124 & 100 & 12 \\
\hline Mereury (ppo) & 0.94 & 0.84 & . 0.6H & $2.6 \mathrm{X}$ & 0.64 & 101 & i8 \\
\hline Nicke! (ppos) & 《AM & ४4H & «4H & ४४H & $\langle 4 H$ & 88 & 21 \\
\hline Lead (ppb) & 9.21 & $5.1 k$ & $6.7 \mathrm{~N}$ & 7.34 & 4.0H & 89 & 18 \\
\hline Antiaony (ppb) & $<0.7 N$ & $<0.611$ & $<0 . \pi n$ & $<0.74$ & $<0.74$ & 113 & 4 \\
\hline Selenive $(p p b)$ & $<0.7 N$ & $<0.7 x$ & 80.74 & $<0.7 \mathrm{H}$ & $<0.7 \mathrm{H}$ & 97 & 4 \\
\hline Thalliua (ppo) & $\$ 0.8$ & $<0.7$ & $<0.8$ & $<0.8$ & $<0.8$ & 110 & 6 \\
\hline $2 \ln 5(p p b)$ & .. 334 & 211 & 244 & $21 \%$ & $19 \pi$ & 97 & 0 \\
\hline
\end{tabular}

Arialysas performed in accordance with methoas

approved by the USEFt.

COAMENT: $W$ = Results empressed in FFM

orid reforted or a dry weight besis.

Respectuily subnitted,

CC. MF. T. GORMAN/ATL

B. 6

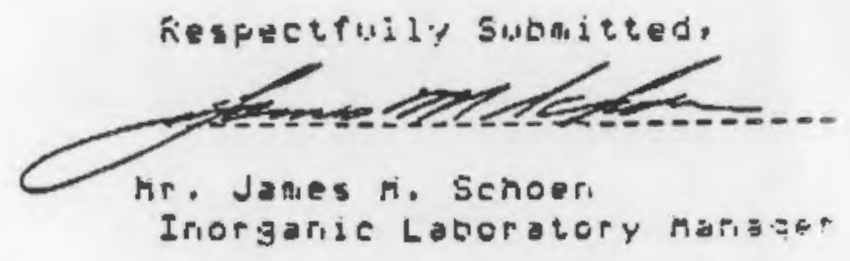




\section{DISTRIBUTION}

No. of

Copies

\section{OFFSITE}

10 DOE/Office of Scientific and Technical Information

DOE Office of the Assistant GTN

Secretary for Nuclear Energy

Washington, DC 20545

ATTN: J. A. Coleman

DOE Office of Defense Waste \& Transportation Management GTN

Washington, DC 20545

ATTN: S. P. Mathur

DOE Office of Remedial Action

\& Waste Technology

GTN

Washington, DC 20545

ATTN: H. F. Walter, NE-24

DOE Albuquerque Operations office

P. 0. Box 5400

Albuquerque, NM 87185

ATTN: J. McGough

4 DOE Idaho Operations Office 785 DOE Place

Idaho Falls, ID 83402

ATTN: M. W. Shupe

J. P. Hamric

C. R. Enos

S. A. Morreale

2 Argonne National Laboratory 9700 South Cass Avenue

Argonne, IL 60439

ATTN: C. S. Abrams

J. H. Kittel
No. of

Copies

5 Arnold Engineering Development Center

Arnold AFB, TN 37389

ATTN: J. K. Lominac (5)

2 Battelle Memorial Institute Project Management Division 505 King Avenue

Columbus, $\mathrm{OH} 43201$

ATTN: W. A. Carbiener

S. H. Basham

6 EG\&G Idaho

P.0. Box 1625

Idaho Falls, ID 83415

ATTN: B. L. Charboneau, 3421

T. L. Clements, 4201

J. L. Landon, 3507

R. R. Piscitella, 352B

T. L. Rasmussen, 3528

A. D. Rodgers, 2411

3 E.I. du Pont de Nemours Company

Savannah River Laboratory

Aiken, SC 29B0l

ATTN: M. D. Boersma

W. Holmes

J. Steele

Electric Power Research Institute

3412 Hillview Avenue

P.0. Box 10412

Palo Alto, CA 94304

ATTN: R. A. Shaw

3 Geosafe Corporation

Kirkland Park Place

303 Park Place, Suite 126

Kirkland, WA 98033

ATTN: V. F. FitzPatrick

J. E. Hansen

T. G. Murray 
No. of

Copies

3 Laboratory Records Department P.0. Box X

Bldng. 4500-N, Room H-205

Oak Ridge National Laboratory

Oak Ridge, TN 37831

Lawrence Livermore National Laboratory

University of California

P.0. Box 808

Livermore, CA 94550

ATTN: L. D. Ramspott

2 Los Alamos National Laboratory

P.0. Box 1663

Los Alamos, NM 87544

ATTN: D. T. Oakley

J. Winzel

11 Martin Marietta Energy Systems Inc.

FEDC Building

104 Union Valley Road

Oak Ridge, TN 37831

ATTN: B. E. Adams

G. L. Dippo (10)

5 Oak Ridge National Laboratory

P.0. Box Y

Oak Ridge, TN 37830

ATTN: R. Adams

L. Mezga

T. H. Row

B. P. Spalding

T. Tamura

2 Rockwell International

Rocky Flats Plant

P.0. Box 464

Golden, CO 80402-0464

ATTN: P. G. Hagen

K. McKinley

West Valley Nuclear Services Company

P.0. Box 191

West Valley, NY 14171

ATTN: J. M. Pope
No. of

Copies

ONSITE

4 DOE Richland Operations Office

C. E. Collantes

R. E. Gerton

R. B. Goranson

D. M. Smith

7 Westinghouse Hanford Company

J. W. Cammann

K. A. Gasper

R. E. Lerch

H. E. McGuire

D. A. Turner

D. D. Wodrich

R. D. Wojtasak

51 Pacific Northwest Laboratory

S. 0. Bates

W. F. Bonner

J. L. Buelt

H. C. Burkholder

J. G. Carter

T. T. Claudson

R. K. Farnsworth

W. 0. Heath

S. S. Koegler

W. L. Kuhn

J. L. McEl roy

S. J. Mitchel1

K. H. Oma

M. E. Peterson

M.A.H. Reimus

C. L. Timmerman (30)

Publishing Coordination

Technical Report Files (5) 